\title{
C3G knock-down enhances migration and invasion by increasing Rap1-mediated p38a activation, while it impairs tumor growth through p38a-independent mechanisms
}

\author{
Neibla Priego ${ }^{1,2, *}$, María Arechederra ${ }^{1,2, *}$, Celia Sequera ${ }^{1,2}$, Paloma Bragado ${ }^{3}$, Ana \\ Vázquez-Carballo ${ }^{1,2}$, Álvaro Gutiérrez-Uzquiza ${ }^{1,7}$, Víctor Martín-Granado ${ }^{4}$, Juan \\ José Ventura ${ }^{5}$, Marcelo G. Kazanietz ${ }^{6}$, Carmen Guerrero ${ }^{4}$ and Almudena Porras ${ }^{1,2}$ \\ ${ }^{1}$ Departamento de Bioquímica y Biología Molecular II, Facultad de Farmacia, Universidad Complutense de Madrid, Madrid, \\ Spain \\ 2 Instituto de Investigación Sanitaria del Hospital Clínico San Carlos (IdISSC), Madrid, Spain \\ ${ }^{3}$ Institut d'Investigacions Biomediques August Pi i Sunyer (IDIBAPS), Barcelona, Spain \\ ${ }^{4}$ Centro de Investigación del Cáncer, IBMCC, Departamento de Medicina, Facultad de Medicina, Universidad de Salamanca, \\ Instituto de Investigaciones Biomédicas de Salamanca (IBSAL), Salamanca, Spain \\ ${ }^{5}$ Translational Cell and Tissue Research, Department of Imaging and Pathology, Leuven University, Leuven, Belgium \\ ${ }^{6}$ Department of Systems Pharmacology and Translational Therapeutics, Perelman School of Medicine, University of \\ Pennsylvania, Philadelphia, PA, USA \\ 7 Present address: Department of Cancer Biology, Biomedical Research Building II/III, School of Medicine, University of \\ Pennsylvania, Philadelphia, PA, USA \\ * These authors have contributed equally to this experimental work \\ Correspondence to: Almudena Porras, email: maporras@ucm.es \\ Carmen Guerrero, email: cguerrero@usal.es
}

Keywords: C3G; p38 MAPK; Rap1; migration; tumorigenesis

Received: Dcember 10, 2015 Accepted: May 25, 2016

Published: June 07, 2016

\section{ABSTRACT}

C3G, a Guanine nucleotide Exchange Factor (GEF) for Rap1 and R-Ras, has been shown to play important roles in development and cancer. Previous studies determined that C3G regulates cell death through down-regulation of p38a MAPK activity. Here, we found that C3G knock-down in MEFs and HCT116 cells promotes migration and invasion through Rap1-mediated p38a hyper-activation. These effects of C3G were inhibited by Rap1 knock-down or inactivation. The enhanced migration observed in C3G depleted HCT116 cells was associated with reduction in E-cadherin expression, internalization of ZO-1, actin cytoskeleton reorganization and decreased adhesion. We also found that matrix metalloproteases MMP2 and MMP9 are involved in the pro-invasive effect of C3G down-regulation. Additionally, our studies revealed that both C3G and p38a collaborate to promote growth of HCT116 cells in vitro and in vivo, possibly by enhancing cell survival. In fact, knocking-down C3G or p38a individually or together promoted cell death in vitro, although only the double C3Gp38a silencing was able to increase cell death within tumors. Notably, we found that the pro-tumorigenic function of C3G does not depend on p38a or Rap1 activation. Altogether, our studies uncover novel mechanisms by which C3G controls key aspects of tumorigenesis.

\section{INTRODUCTION}

C3G (Crk SH3-domain-binding guanine-nucleotide- releasing factor) is a Guanine nucleotide Exchange Factor (GEF) for Rap1 and R-Ras proteins [1-3] that is essential for embryonic development due to its function in integrinmediated cellular adhesion and migration [3]. 
$\mathrm{C} 3 \mathrm{G}$ has been shown to regulate cell migration in different ways depending on the context. For example, C3G deficiency enhances migration in mouse embryonic fibroblasts (MEFs), while it impairs cell adhesion and delays cell spreading [3-4]. In contrast, the absence of $\mathrm{C} 3 \mathrm{G}$ or a hypermorphic $\mathrm{C} 3 \mathrm{G}$ mutation leads to impaired cortical [5] and sympathetic preganglionic neurons migration [6], respectively. On the other hand, C3G overexpression leads to opposite outcomes in different cell types, as it increases migration of glomerulal epithelia cells in glomerulonephritis [7], while decreasing migration in highly invasive breast carcinoma cells [8]. Several lines of evidence suggest that $\mathrm{C} 3 \mathrm{G}$ can exert effects through mechanisms that are independent of its GEF activity [9$11]$.

The function of $\mathrm{C} 3 \mathrm{G}$ in cell migration has been described to be mediated, at least in part, by its main target, Rap1 [3, 12-13]. C3G overexpression can also promote c-Abl-induced filopodia formation through mechanisms independent of its catalytic activity [14]. C3G is known to regulate cell-cell interactions [13, 15], where E-cadherin plays a key role [13]. Mechanistically, it has been found that $\mathrm{C} 3 \mathrm{G}$ binds intracellular E-cadherin, and this leads to activation of Rap-1 and E-cadherin translocation [13].

The function of $\mathrm{C} 3 \mathrm{G}$ in human cancer has been a subject of controversy for many years. In mouse fibroblasts, $\mathrm{C} 3 \mathrm{G}$ can act as a tumor suppressor gene, as it prevents malignant transformation induced by several oncogenes $[9-10,16]$. Accordingly, C3G expression is reduced in cervical squamous cell carcinoma [17]. In contrast, elevations in $\mathrm{C} 3 \mathrm{G}$ expression have been found in human non-small-cell lung cancer [18]. The expression of the $\mathrm{p} 87 \mathrm{C} 3 \mathrm{G}$ isoform in chronic myeloid leukemia (CML) cells has been causally associated with disease development [19]. Recent data also suggested that C3G, acting through Rap1, induces invasion of epithelial ovarian cancer cells and promotes the secretion of matrix metalloproteases MMP2 and MMP9 [20]. In colon carcinoma, the $\mathrm{C} 3 \mathrm{G}$ gene is frequently demethylated [21], but it remains to be determined whether this epigenetic modification is associated with changes in $\mathrm{C} 3 \mathrm{G}$ expression or if it plays any relevant role in the progression of this cancer.

There is extensive evidence for the involvement of p38 $\alpha$ MAPK in cancer. Like C3G, p38 $\alpha$ has been shown to act also both as a tumor suppressor or tumor promoter depending on the type of cancer and tumor stage [22]. p38 $\alpha$ was found to inhibit tumor initiation by promoting cell cycle arrest and/or inducing apoptosis [22-24]. In contrast, increased levels of phosphorylated (active) p38 $\alpha$ have been correlated with malignancy in various cancer types [22], such as head and neck carcinoma [25]. It has been also reported that at late stages of tumor development, p38 $\alpha$ can promote cell survival [22, 26], migration and invasion, thereby contributing to the metastatic dissemination of cancer cells [22]. Accordingly, p38 $\alpha$ MAPK is required for cell migration in MEFs [27], and several cancer cell lines $[22,28]$. Moreover, p38 $\alpha$ negatively regulates cell adhesion in embryonic stem cells [29] and cardiomyocyte-derived cell lines [30], which would result in an enhanced migratory phenotype. We have recently reported that $\mathrm{p} 38 \alpha$ promotes growth of HCT116 colon cancer cells in vitro and in nude mice, as well as positively regulates migration and invasion [27]. In agreement with these findings, recent studies highlighted a fundamental role for $\mathrm{p} 38 \alpha$ in promoting cell proliferation and survival in a mouse model of colitis-associated tumor induction [31].

Using the CML cell line K562 and MEFs deficient in p38 $\alpha$ and/or C3G, we have previously reported that C3G, through down-regulation of $\mathrm{p} 38 \alpha$ activity, positively or negatively regulates apoptosis, depending on the stimulus [32-33]. C3G and p38 $\alpha$ also display antagonistic roles in the regulation of focal adhesion (FA) complex formation in K562 cells [34]. Based on these previous findings, in the present study we wished to determine if $\mathrm{p} 38 \alpha$ could also mediate the effect of $\mathrm{C} 3 \mathrm{G}$ on cell migration and invasion. In addition, we investigated if the $\mathrm{C} 3 \mathrm{G} / \mathrm{p} 38 \alpha$ pathway could be potentially involved in tumor growth. Our results revealed that $\mathrm{C} 3 \mathrm{G}$ inhibits cell migration and invasion by interfering with Rap1-mediated p $38 \alpha$ activation. On the other hand, both $\mathrm{C} 3 \mathrm{G}$ and $\mathrm{p} 38 \alpha$ are capable of promoting colon carcinoma tumor growth mainly through different mechanisms.

\section{RESULTS}

\section{C3G silencing increases migration and invasion of MEFs through a mechanism dependent on p38a MAPK}

In the first set of experiments, we took advantage of loss-of-function approaches to establish the involvement of C3G and p38 $\alpha$ in MEF cell motility. As shown in Figure $1 \mathrm{~A}$ and $1 \mathrm{~B}$, wound healing assays revealed that $\mathrm{C} 3 \mathrm{G}$ knock-down enhanced cell migration in wt MEFs, but not in $\mathrm{p} 38 \mathrm{\alpha}-/$ - cells. Moreover, time-lapse microscopy analysis showed that C3G knock-down MEFs expressing p38 $\alpha$ lost cell-cell interactions, escaped from the wound border, and moved away (Suppl. Videos). In contrast, MEFs lacking p38 $\alpha$ moved slowly and collectively, maintaining cell-cell interactions, and in these cells, C3G knock-down has not a major effect.

To determine if $\mathrm{C} 3 \mathrm{G}$ was acting through its main target, Rap1, we evaluated the effect of a dominant negative Rap1 (DNRap1) construct using a MEFs cell line previously established, where Rap1-GTP levels are very low [33]. Figure $1 \mathrm{~A}$ and $1 \mathrm{~B}$ show a reduction in migration in wt cells expressing DNRap1, which correlates with the reduction in phospho-p38a levels (Suppl. Fig 1). In 
p38 $\alpha$-/- MEFs, no significant effect was observed. To further demonstrate the relevance of p38 $\alpha$, the effect of the selective $\mathrm{p} 38 \alpha / \beta$ inhibitor SB203580 was examined. Treatment with this p38 inhibitor prevented the enhancing effect of $\mathrm{C} 3 \mathrm{G}$ knock-down on migration in wt MEFs and decreased the migratory ability of non-silenced cells (Figure 1C and Suppl. Figure 2). These results strongly indicate that $\mathrm{p} 38 \alpha$ mediates the pro-migratory effect caused by $\mathrm{C} 3 \mathrm{G}$ silencing.

Next, we evaluated the effect of $\mathrm{C} 3 \mathrm{G}$ on invasion. C3G knock-down markedly enhanced invasion of wt MEFs through Matrigel, but not that of p38 $\alpha-/-$ cells (Figure 2A and 2B). Cells lacking p38 $\alpha$ had a very low invasive capacity. Moreover, the expression of the DNRap1 impaired invasion of wt MEFs. These results indicate that the increased invasion induced by $\mathrm{C} 3 \mathrm{G}$ depletion requires $\mathrm{p} 38 \alpha$ activation. This was further supported by the inhibitory effect of SB203580 on the invasive effect on Matrigel (Figure 2C) and collagen (data not shown) caused by C3G knock-down.

MMPs are relevant for extracellular matrix degradation during migration and invasion [35-36], and some of them are regulated by $\mathrm{p} 38 \alpha$, such as MMP2 and MMP9 [27, 37]. As shown in Figure 2D, MMP2 and MMP9 activities were higher in wt than in p38 $\alpha-/-$ MEFs, and they were further increased upon $\mathrm{C} 3 \mathrm{G}$ knock-down in wt MEFs. In contrast, activities of these MMPs decreased in wt cells expressing DNRap1. In addition, treatment with SB203580 markedly reduced MMP9 activity in wt cells, with or without $\mathrm{C} 3 \mathrm{G}$ silencing, and slightly inhibited MMP2 activity (Suppl. Figure 3). These data suggest the involvement of MMP2 and MMP9 in the pro-invasive effect caused by $\mathrm{C} 3 \mathrm{G}$ knock-down as well as in the inhibitory effect of DNRap1.

A

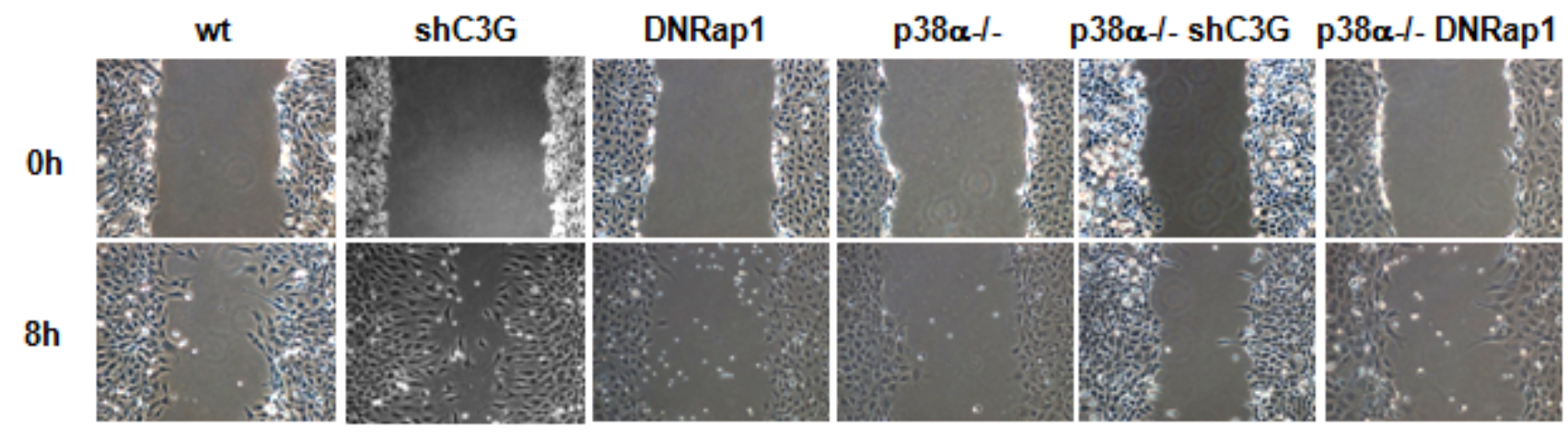

B

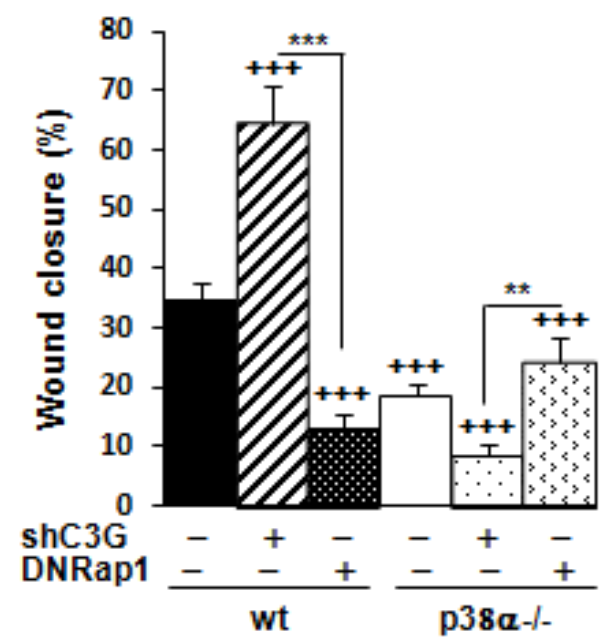

C

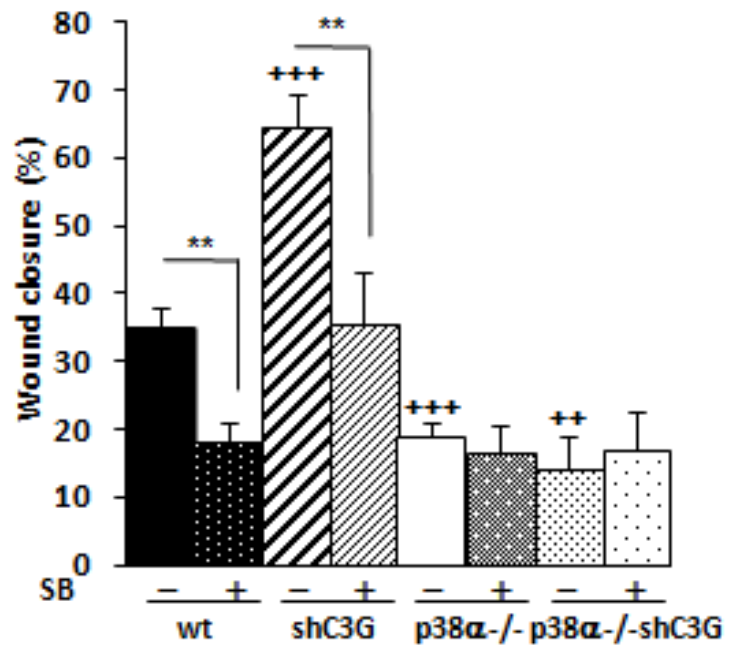

Figure 1: C3G knock-down enhances migration of MEFs through a mechanism dependent on p38a. Wound healing assay. MEFs (wt and p38 $\alpha-/-$, with (shC3G) or without C3G knock-down or expression of DNRap1 (DNRap1)) were maintained in the absence of serum and allowed to migrate. A. Representative images from phase contrast microscope after 0 and 8 h of migration. B. and C. Histograms show the mean \pm S.E.M. of the percentage of wound closure $(n=4) .{ }^{++} p<0.01$ and ${ }^{+++} p<0.001$, versus ${ }^{\mathrm{wt}} ;{ }^{* *} p<0.01 ;{ }^{* * *} p<0.001$, compared as indicated. C. Effect of $\mathrm{p} 38 \alpha / \beta$ inhibition with the chemical inhibitor, SB203580 $(10 \mu \mathrm{M})$, on cell migration. 
A

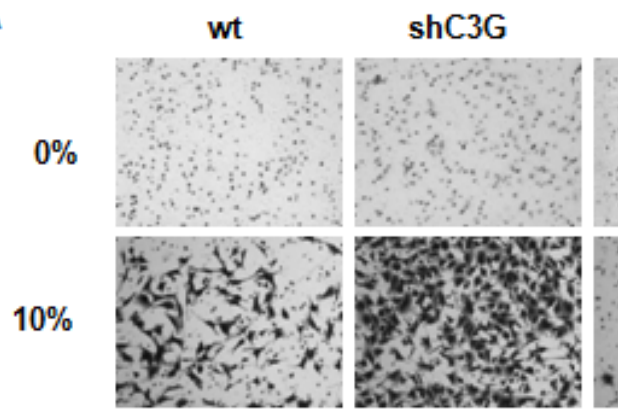

DNRap1

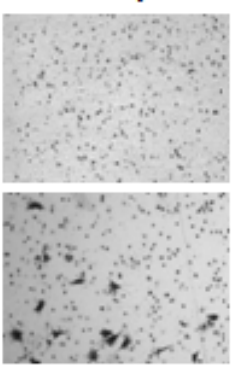

p38 $\alpha-1-$

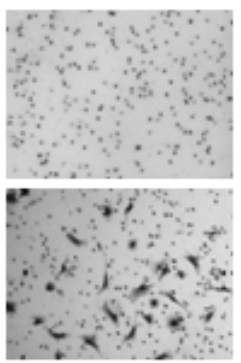

p38 $\alpha-1-$ shC3G p38 $\alpha-$ - DNRap1
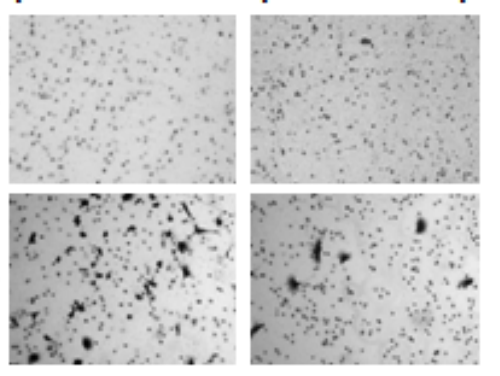

B

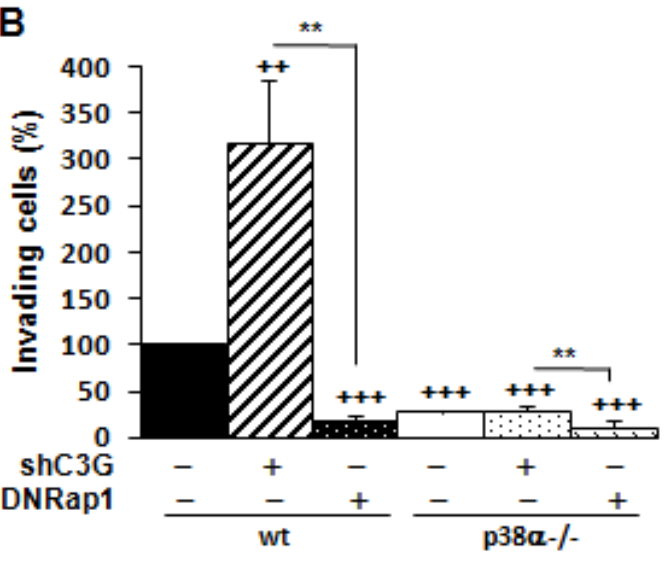

D

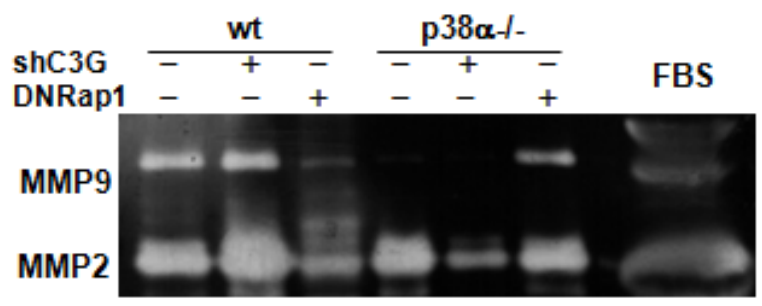

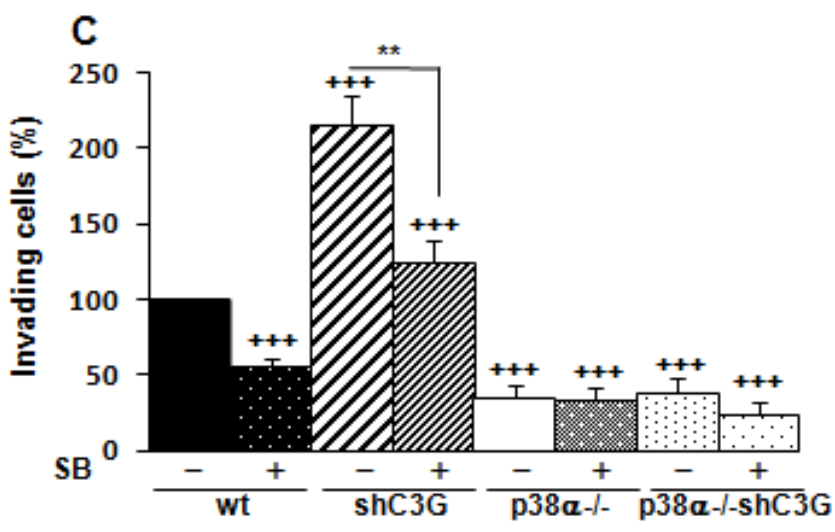

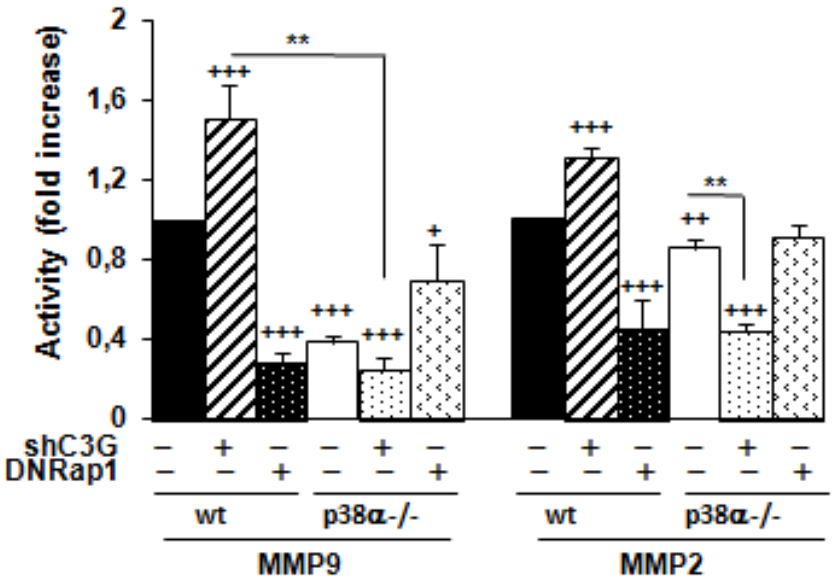

Figure 2: C3G silencing increases the invasive capacity of MEFs by a mechanism mediated by p38 $\alpha$ and dominant negative Rap1 impairs invasion. MEFs (wt and p38 $\alpha-/-$, with (shC3G) or without C3G knock-down or expression of DNRap1 (DNRap1)) were maintained in the absence of serum for the last 24h. A., B. and C. Invasion through Matrigel using FBS (10\%) as chemoattractant. A. Representative images of invading cells after staining with crystal violet (phase contrast microscope). B. and C. Histograms show the mean value \pm S.E.M. of the percentage of invading cells $(n=4) .{ }^{++} p<0.01$ and ${ }^{+++} p<0.001$, versus wt; ${ }^{* *} p<0.01$, compared as indicated. C. Effect of p38 $\alpha / \beta$ inhibition with SB203580 $(10 \mu \mathrm{M})$ on cell invasion. D. Zymographic analysis of MMP2 and MMP9 activities using gelatin as the substrate and FBS as a control. Representative zymogram (left panel). Histogram (right panel) showing the mean \pm S.E.M. of the densitometric analysis of gelatinase areas expressed as fold increase of the control value $(n=6) .{ }^{+} p<$ $0.05,{ }^{++} p<0.01$ and ${ }^{++} p<0.001$, versus $\mathrm{wt} ;{ }^{* *} p<0.01$, compared as indicated. 
$\mathrm{C} 3 \mathrm{G}$ is known to regulate migration, invasion, as well as the tumorigenic activity of various cancer cell types [8, 15, 17-20]. However, the functional relevance of $\mathrm{C} 3 \mathrm{G}$ in colon carcinoma has not been characterized. First, we examined $\mathrm{C} 3 \mathrm{G}$ protein levels in human colon carcinoma cell lines with different invasive capacities: HCT116 cells (low invasive ability), SW480 and SW620 cells (high invasive ability). As shown in Figure 3A, the highest $\mathrm{C} 3 \mathrm{G}$ expression levels were found in the least invasive cell line, HCT116 cells, thus suggesting an inverse correlation between $\mathrm{C} 3 \mathrm{G}$ protein levels and colon carcinoma cells invasive capacity. Next, we determined the effect of $\mathrm{C} 3 \mathrm{G}$ down-regulation on the migratory and invasive capacities of HCT116 cells. Notably, knockingdown $\mathrm{C} 3 \mathrm{G}$ in parental cells led to a significant upregulation of the levels of phospho-p38 $\alpha$, phospho-Akt and phospho-ERKs in response to serum (Figure 3B), as previously described in MEFs [33]. Hence, we next determined the effect of $\mathrm{C} 3 \mathrm{G}$ knock-down on migration and whether this effect was dependent on $\mathrm{p} 38 \alpha$. Figure $3 \mathrm{C}$ shows that $\mathrm{C} 3 \mathrm{G}$ silencing enhanced migration in HCT116 cells expressing p38 $\alpha$, but not in those subjected to p38 $\alpha$ depletion. Moreover, inhibition of $\mathrm{p} 38 \alpha / \beta$ with SB203580 prevented the enhancement of migration induced by $\mathrm{C} 3 \mathrm{G}$ knock-down in cells expressing p38 $\alpha$ (Figure 3C) and reduced the migratory capacity of non-silenced cells. These results suggest that $\mathrm{C} 3 \mathrm{G}$ inhibits migration through p38 $\alpha$ inhibition.

To assess if the effects of $\mathrm{C} 3 \mathrm{G}$ were mediated by Rap1, Rap1 was knocked-down in parental HCT116 cells using two different shRNAs. Figure 3D shows that Rap1 levels were significantly reduced by both shRNAs, which reduced migration. This suggests that Rap1 does not mediate $\mathrm{C} 3 \mathrm{G}$ effects on migration. To confirm this, Rap1 was transiently knocked-down in C3G silenced HCT116 cells. Surprisingly, Rap1 knock-down prevented the increase in migration induced by $\mathrm{C} 3 \mathrm{G}$ knock-down in cells expressing p38 $\alpha$ (Figure $3 \mathrm{E}$ ), in a similar way that p38 $\alpha / \beta$ inhibition did. Accordingly, phospho-p38 MAPK levels markedly decreased upon Rap 1 knock-down in cells expressing p38 $\alpha$, either with or without $\mathrm{C} 3 \mathrm{G}$ silencing (Figure 3F). These results indicate that in the absence of C3G, compensatory mechanisms are activated and other Rap1 GEFs could possibly activate Rap1. This would lead to increase p38 $\alpha$ activation and consequently, enhance migration.

We also found that $\mathrm{C} 3 \mathrm{G}$ knock-down reduced adhesion of HCT116 cells expressing p38a (Figure 4A), which was prevented by Rap1 knock-down (Suppl. Figure 4). Both single p38 $\alpha$ and Rap1 depletion increased adhesion, as also observed upon inhibition of $\mathrm{p} 38 \alpha / \beta$ with SB203580 (Figure 4B). Indeed, C3G knock-down cells expressing $\mathrm{p} 38 \alpha$ showed the lowest adhesion, which might favor migration. Accordingly, invasion of these cells through Matrigel using HGF as chemoattractant was increased (Figure 4C), and this effect was dependent on p38 $\alpha$ activation, as p38 $\alpha$ knock-down or SB203580 impaired the invasive response (Figure 4C). Similarly, Rap1 knock-down abrogated invasion of parental cells (Figure 4D) and impaired the pro-invasive effect caused by $\mathrm{C} 3 \mathrm{G}$ silencing (Figure $4 \mathrm{E}$ ).

MMP2 and MMP9 activities were higher in HCT116 cells expressing p38 $\alpha$ relative to p38 $\alpha$ knockdown cells (Figure 4F). These differences were further increased upon $\mathrm{C} 3 \mathrm{G}$ silencing (Figure 4F). In contrast, Rap1 knock-down decreased MMP2 and MMP9 activities in cells expressing p38 $\alpha$ (Suppl. Figure 5). Other MMPs reported to be important for invasion of colon carcinoma cells (MMP7, MMP10 and MMP13) did not show any significant change in expression as a consequence of $\mathrm{C} 3 \mathrm{G}$ and/or p38 $\alpha$ knock-down, as determined by RT-qPCR (data not shown).

\section{Mechanisms involved in the regulation of migration by C3G}

Cell migration involves the re-organization of F-actin cytoskeleton and the generation of structures such as ruffles, filopodia and lamellipodia [38]. These effects can be regulated by $338 \alpha$ [28]. Changes in the expression and/or subcellular localization of cell-cell contact proteins also occur during migration [38-40]. To gain further insights into the mechanisms involved in the regulation of migration and invasion by $\mathrm{C} 3 \mathrm{G}$, we analyzed F-actin cytoskeleton organization, as well as the levels and subcellular localization of relevant cell junction proteins, namely E-cadherin and ZO-1.

E-cadherin is known to interact with $\mathrm{C} 3 \mathrm{G}$, which participates in the maturation of E-cadherin-based cellcell contacts [41-42]. E-cadherin levels were substantially reduced in HCT116 cells subjected to $\mathrm{C} 3 \mathrm{G}$ knock-down (Figure 5A), with or without p38 $\alpha$ depletion. Silencing p38 $\alpha$ also led to E-cadherin down-regulation, and indeed, the largest reduction in E-cadherin levels was observed in cells with double C3G-p38 $\alpha$ knock-down. As this reduction in E-cadherin did not correlate with the migratory and invasive capacity of the cells (see Figure $3 \mathrm{C}$ and 4C), we analyzed changes in E-cadherin subcellular localization by confocal microscopy. In all cases, E-cadherin was primarily located in the plasma membrane (Figure 5B), although it was partially internalized in cells subject to dual knock-down.

Although no significant changes in ZO-1 total protein levels could be observed upon $\mathrm{C} 3 \mathrm{G}$ knock-down in cells expressing $\mathrm{p} 38 \alpha$ (Figure $5 \mathrm{~A}$ ), this protein was found to be internalized (Figure $5 B$ ). In contrast, in p38 $\alpha$ silenced HCT116 cells, ZO-1 was mainly present in the plasma membrane, as also observed in cells subjected to double $\mathrm{C} 3 \mathrm{G} / \mathrm{p} 38 \alpha$ knock-down, where ZO-1 total levels were reduced (Figure $5 \mathrm{~A}$ and $5 \mathrm{~B}$ ). These data suggest that cell-cell contacts, particularly tight junctions, are partially 

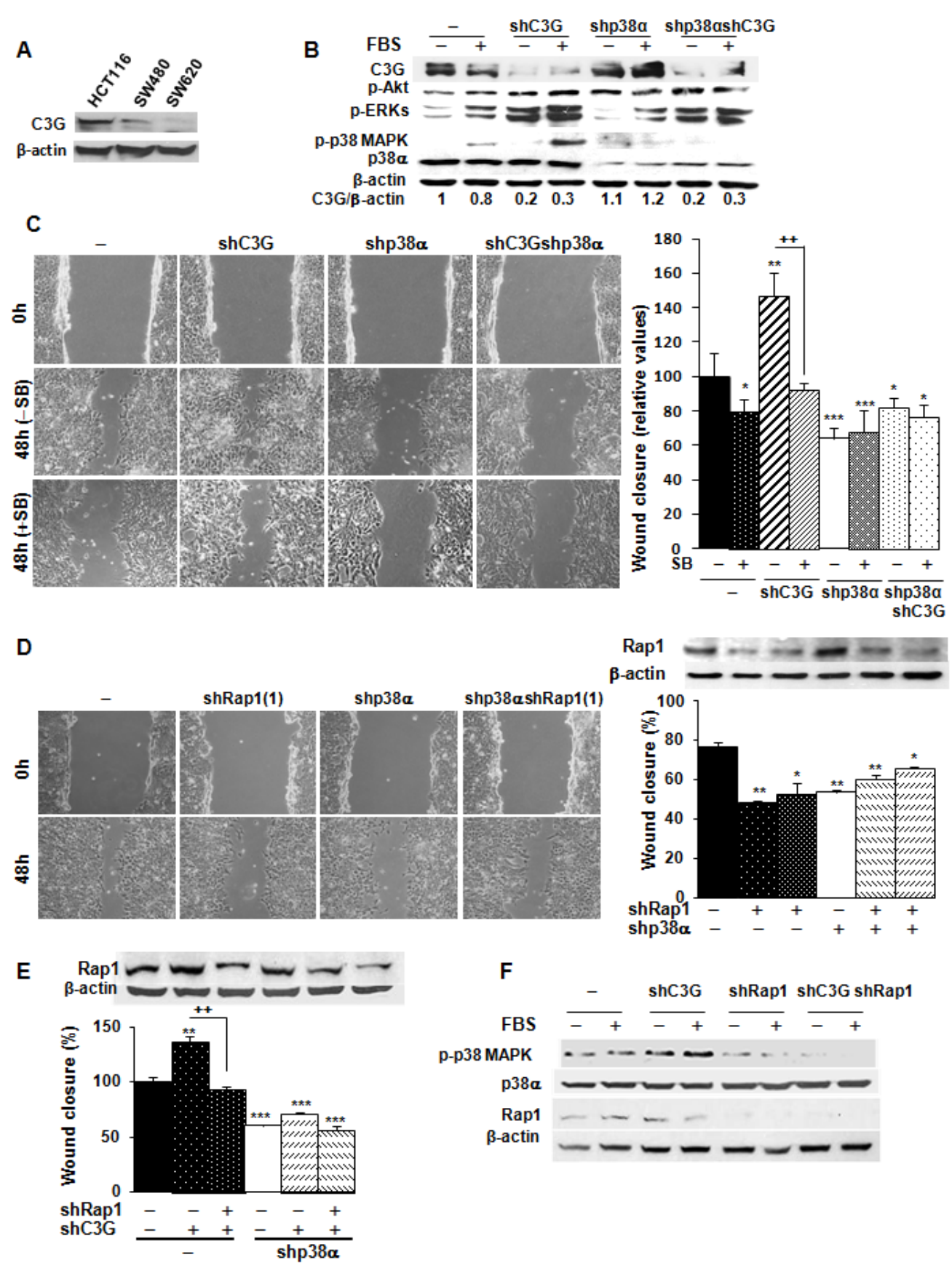

Figure 3: C3G knock-down enhances migration of HCT116 cells by increasing Rap1-mediated p38a activation. HCT116 (non-silenced (-) and p38 $\alpha$ knock-down (shp38 $\alpha$ ); with (shC3G) or without C3G knock-down; with (shRap1(1) and shRap1(2)) or without Rap1 knock-down), SW480 and SW620 cells were used. A. C3G protein expression in HCT116, SW480 and SW620 cells analyzed by Western-blot and normalized with $\beta$-actin. B. Western-blot analysis of P-Akt, P-ERKs and P-p38 MAPK levels normalized with $\beta$-actin. p38 $\alpha$ and C3G were measured as a control of their expression. C. Wound healing assays. Left panel, representative images from phase contrast microscope after 0 and $48 \mathrm{~h}$ of migration, in the absence or presence of $\mathrm{p} 38 \alpha / \beta$ inhibitor, SB203580 $(10 \mu \mathrm{M})$. Right panel, the histogram shows the mean \pm S.E.M. of the percentage of wound closure $(n=4) .{ }^{*} p<0.05,{ }^{* *} p<0.01 ;{ }^{* * *} p<0.001$, versus non-silenced cells; ${ }^{++} p<0.01$, compared as indicated. D. Effect of Rap1 knock-down using two different shRNAs. Left panel, representative images from phase contrast microscope after 0 and $48 \mathrm{~h}$ of migration upon transient Rap1 silencing using one of the shRNAs against Rap1. Right panel, Rap1 protein expression analyzed by Western-blot and normalized with $\beta$-actin (upper site) and histogram (lower site) showing the mean \pm S.E.M. of the percentage of wound closure using the two different shRNAs against Rap1 $(n=4) .{ }^{*} p<0.05,{ }^{* *} p<0.01$ versus non-silenced cells. E. Effect of C3G and Rap1 double knock-down on wound healing closure. Rap1 protein expression analyzed by Western-blot and normalized with $\beta$-actin (upper panel) and histogram (lower panel) showing the mean \pm S.E.M. of the percentage of wound closure $(n=$ 3). ${ }^{* *} p<0.01$ and ${ }^{* * *} p<0.001$, versus non-silenced cells; ${ }^{+} p<0.01$, compared as indicated. F. Analysis of $\mathrm{p} 38 \alpha$ activation. Western-blot analysis of P-p38 MAPK, p38 $\alpha$ and Rap1 levels normalized with $\beta$-actin in cells expressing p38 $\alpha$. 
A

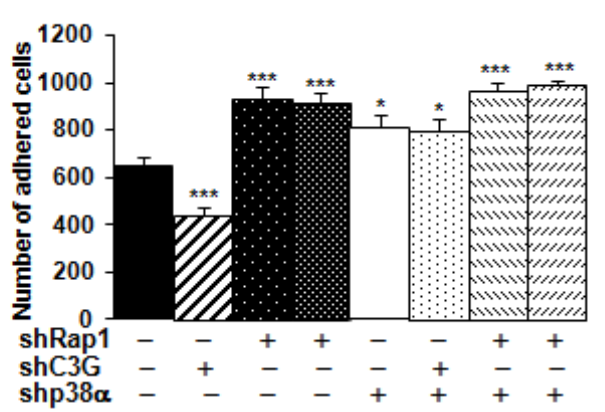

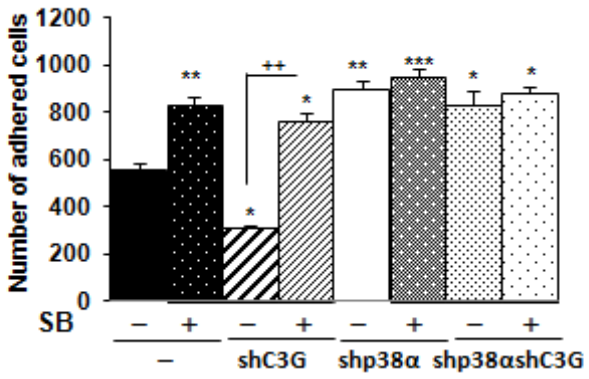

C
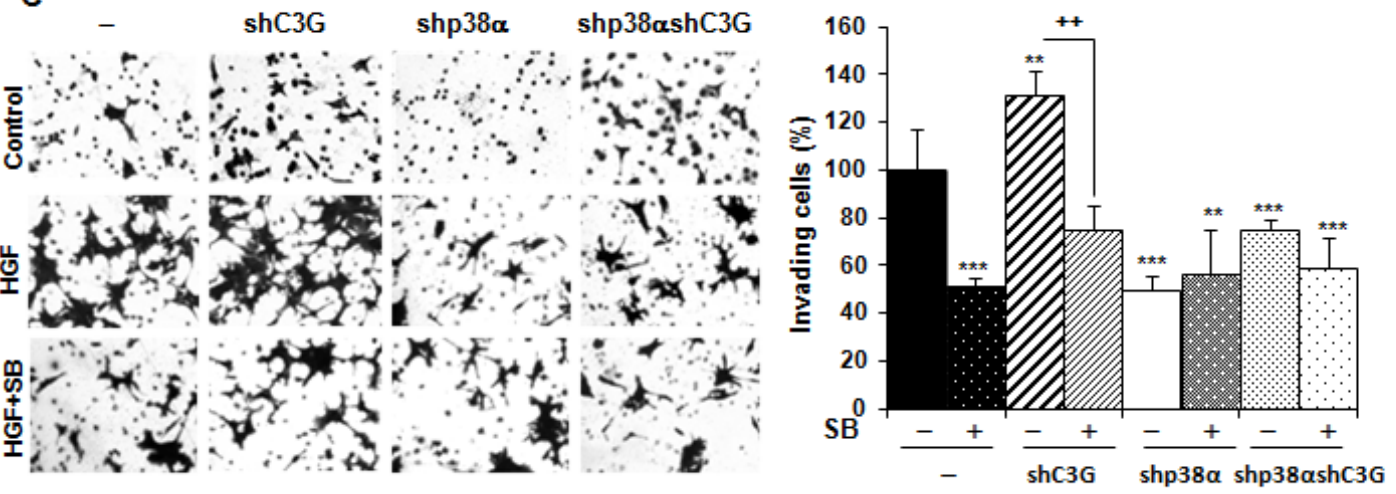

D
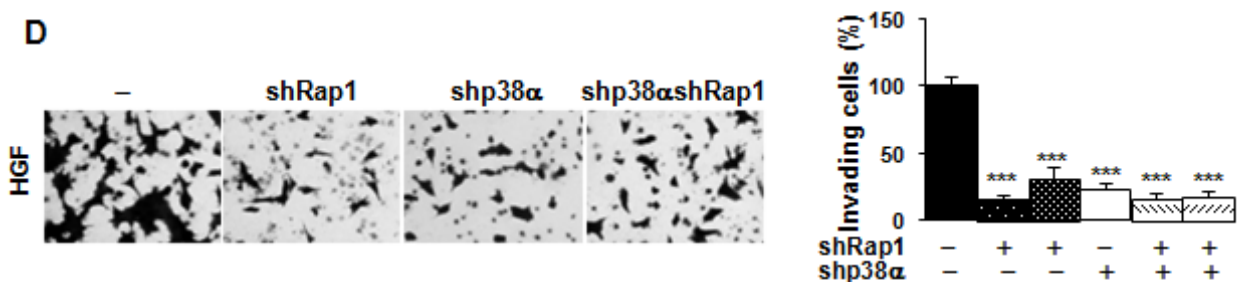

E
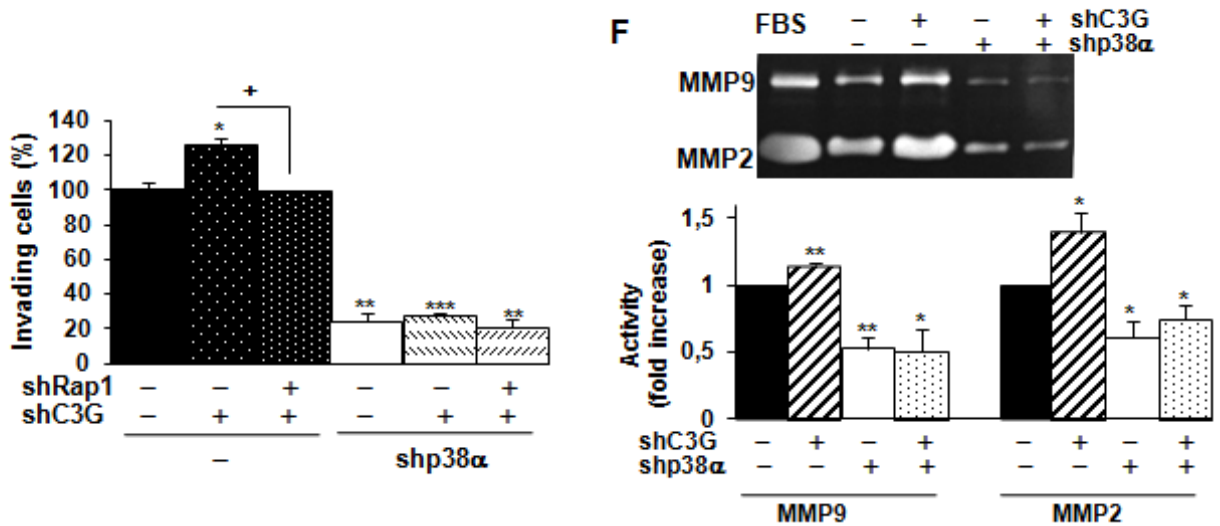

Figure 4: C3G silencing promotes invasion of HCT116 cells by a mechanism mediated by p38a, but not by Rap1. Effect of C3G knock-down on adhesion. HCT116 cells (non-silenced (-) and p38 a knock-down (shp38a); with (shC3G) or without C3G knockdown; with (shRap1) or without Rap1 knock-down) were maintained in the presence (adhesion assays) or absence (invasion assays) of serum and in the presence or absence of the $\mathrm{p} 38 \alpha / \beta$ inhibitor, SB203580 $(5 \mu \mathrm{M})$. A. and B. Adhesion assays. Histograms show the mean \pm S.E.M. of the number of adhered cells $1 \mathrm{~h}$ after platting. C. and D. Invasion through Matrigel using HGF as chemoattractant. Left panels, representative images of invading cells after staining with crystal violet (phase contrast microscope). Right panels, histograms showing the mean value \pm S.E.M. of the percentage of invading cells referred to non-silenced $(100 \%)(n=4) . * * p<0.01, * * * p<0.001$, versus non-silenced cells; ${ }^{++} p<0.01$, compared as indicated. E. Effect of C3G and Rap1 double knock-down on invasion through Matrigel. The histogram shows the mean value \pm S.E.M. of the percentage of invading cells referred to non-silenced $(100 \%) . n=3) .{ }^{*} p<0.05, * * p<$ $0.01,{ }^{* * *} p<0.001$, versus non-silenced cells; ${ }^{+} p<0.05$, compared as indicated. F. Zymographic analysis of MMP2 and MMP9 activities using gelatin as the substrate and FBS as a control. Representative zymogram (upper panel). Histogram (lower panel) showing the mean \pm S.E.M. of the densitometric analysis of gelatinase areas expressed as fold increase of the control value $(n=4) .{ }^{*} p<0.05,{ }^{* *} p<0.01$, versus non-silenced cells. 
A
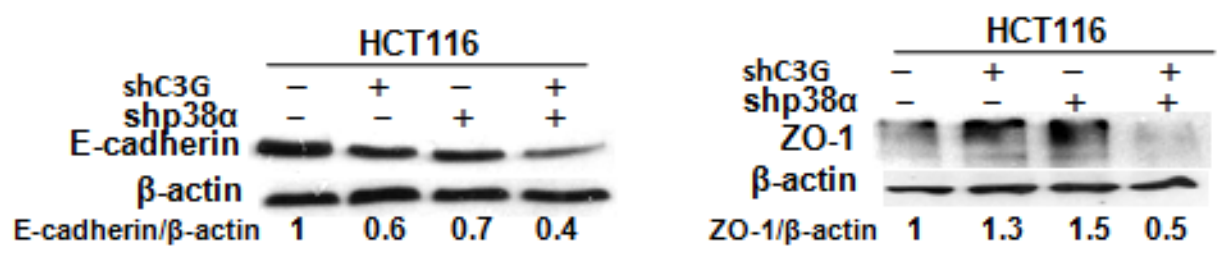

B
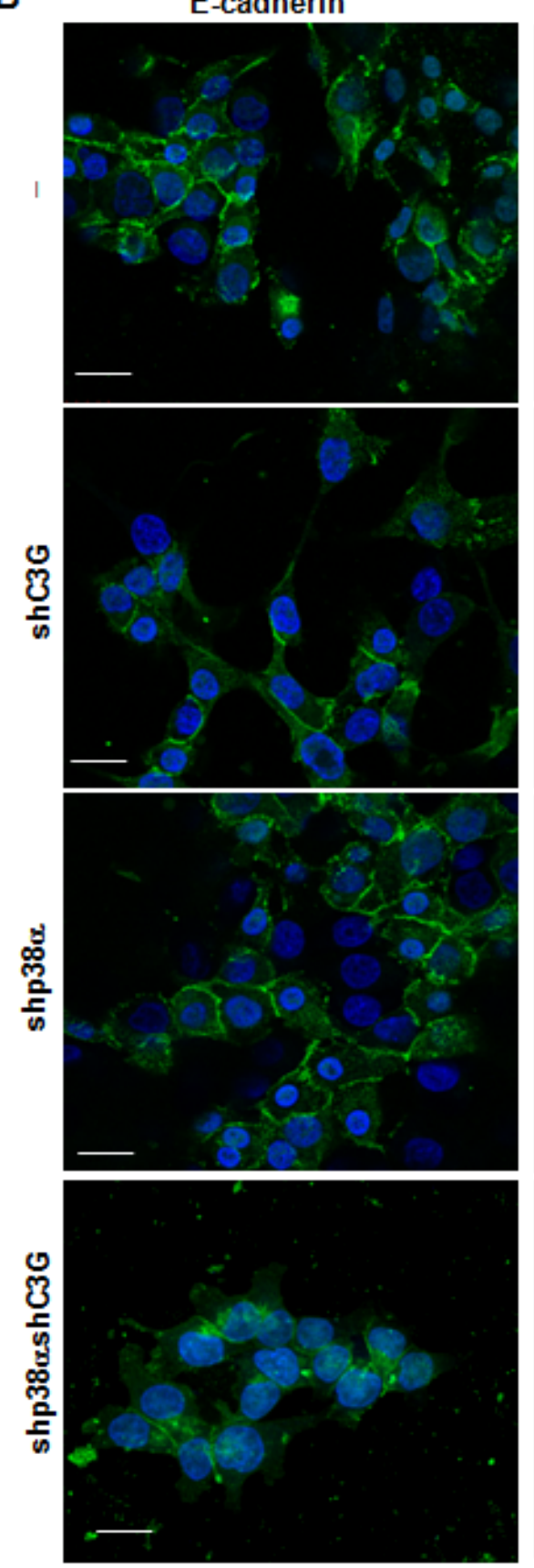

ZO-1
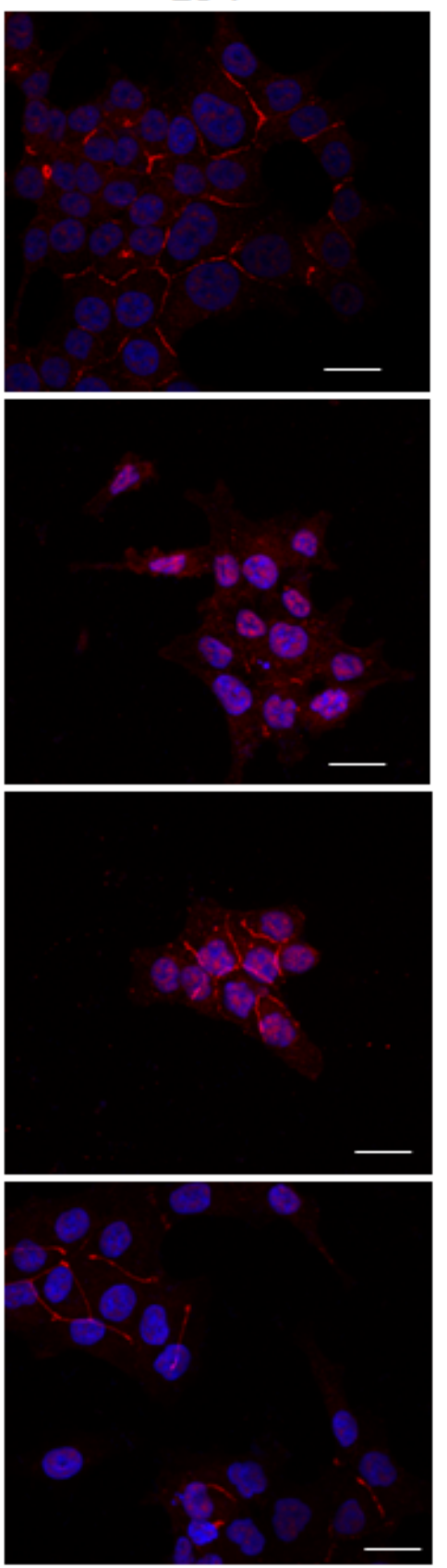

Phalloidin
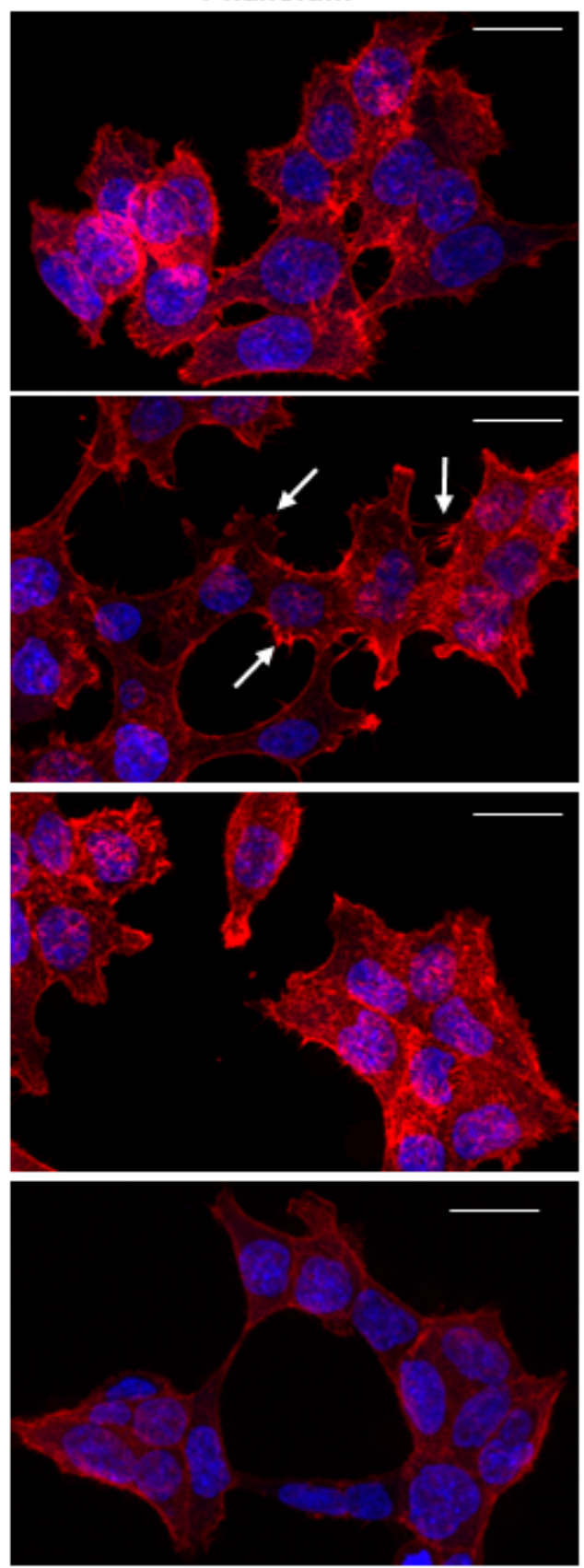

Figure 5: Effect of C3G knock-down on actin-organization, E-cadherin and ZO-1 expression and their subcellular localization in HCT116 cells. Function of p38a MAPK. HCT116 cells (non-silenced (-) and p38 $\alpha$ knock-down (shp38 $\alpha$ ); with $(\mathrm{shC} 3 \mathrm{G})$ or without $\mathrm{C} 3 \mathrm{G}$ knock-down) were used. A. Representative western-blot analysis of E-cadherin and ZO-1 levels normalized with $\beta$-actin. The ratios E-cadherin/ $\beta$-actin and ZO-1/ $\beta$-actin of the densitometric analyses are shown. B. Representative confocal microscopy images of E-cadherin, ZO-1 and actin staining, using specific antibodies or phalloidin, respectively. Scale bar $=20 \mu \mathrm{m}$. Arrows indicates the presence of filopodia. 
disrupted in C3G knock-down HCT116 cells expressing p38 $\alpha$, which would result in enhanced migration.

We also examined F-actin cytoskeleton organization by confocal microscopy. As shown in Figure 5B, the presence of filopodia and lamellipodia was highly noticeable in C3G knock-down HCT116 cells expressing p38 $\alpha$ (see arrows), an effect that correlates with the enhanced migratory capacity of these cells.

A

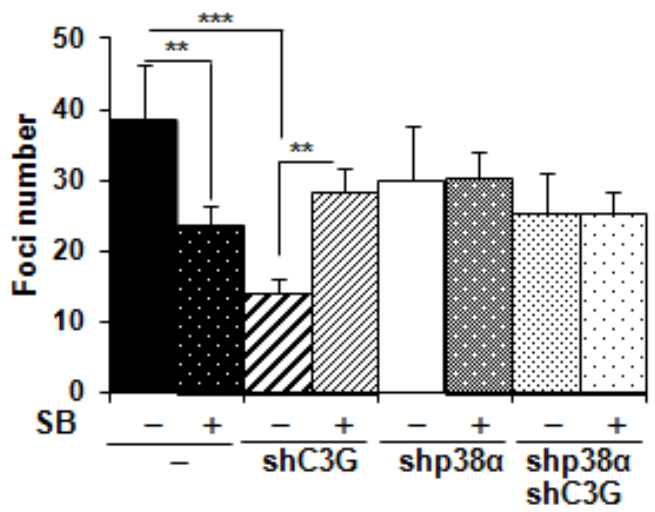

C

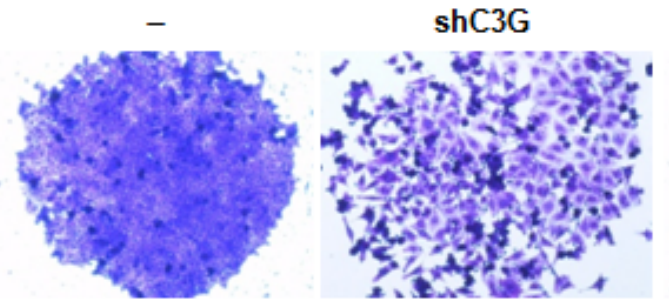

C3G and p38 $\alpha$ MAPK promote HCT116 cells foci formation and in vivo tumor growth through independent mechanisms

Anchorage-dependent growth assays revealed a reduction in the number of foci in $\mathrm{C} 3 \mathrm{G}$ knock-down cells, which was more prominent in cells expressing $\mathrm{p} 38 \alpha$ (Figure 6A). The number of foci was also reduced as a consequence of $\mathrm{p} 38 \alpha$ silencing. These results suggest that

\section{B}
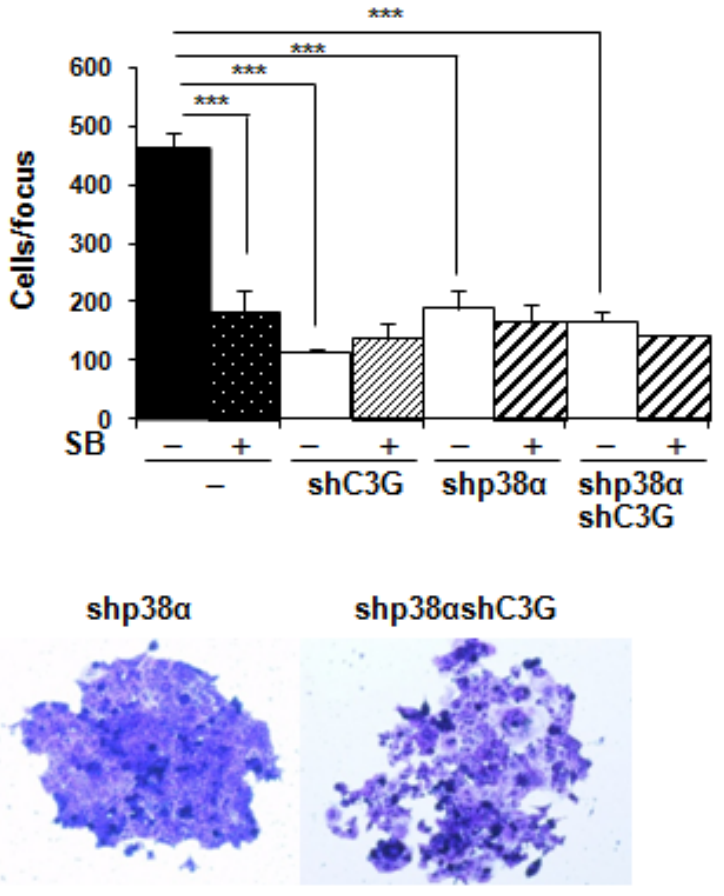

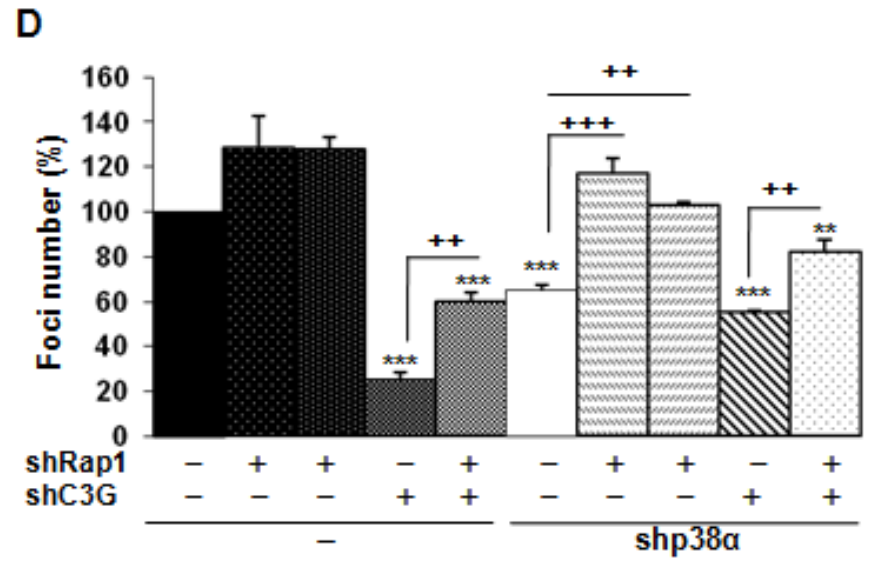

Figure 6: C3G and p38a MAPK, but not Rap1, promote anchorage dependent growth of HCT116 cells. HCT116 cells (non-silenced (-) and p38 $\alpha$ knock-down (shp38 ); with (shC3G) or without C3G knock-down; with (shRap1(1) and shRap1(2)) or without Rap1 knock-down) were used. The effect of p38 $\alpha / \beta$ inhibition by SB203580 $(10 \mu \mathrm{M})$ was also assessed. Anchorage dependent growth assays. . Histograms show the mean \pm S.E.M. of foci number A. and D. or the number of cells per focus $(n=4) \mathbf{B}$.. A. and B. * $p<0.05$, ${ }^{*} p$ $<0.01{ }^{* * *} p<0.001$, compared as indicated. C. Representative images of individual foci. D. Effect of C3G, Rap1 and C3G-Rap1 double knock-down on foci formation. ${ }^{* *} p<0.01,{ }^{* * *} p<0.001$, versus non-silenced cells; ${ }^{++} p<0.01$ and ${ }^{+++} p<0.001$, compared as indicated $(n$ $=3)$. 
both $\mathrm{C} 3 \mathrm{G}$ and $\mathrm{p} 38 \alpha$ promote foci formation probably through distinctive pathways. Moreover, inhibition of p38 $\alpha$ with SB203580 reduced the number of foci in nonsilenced cells, thus recapitulating the effect of p38 $\alpha$ knockdown (Figure 6A). Surprisingly, in C3G depleted cells, the foci number was increased in response to SB203580 treatment, while having no effect on double C3G-p38 $\alpha$ knock-down cells. To gain further insights into the function of $\mathrm{C} 3 \mathrm{G}$ and $\mathrm{p} 38 \alpha$ in foci formation, the number of cells per focus and its morphology was assessed. As shown in Figure 6B, both $\mathrm{C} 3 \mathrm{G}$ and p38 $\alpha$ knock-down decreased the number of cells per focus, whereas SB203580 only caused a reduction in non-silenced cells. Moreover, the foci formed by $\mathrm{C} 3 \mathrm{G}$ knock-down cells, particularly those expressing p38 $\alpha$, showed a reduction in cell-cell contacts, resulting in cell dispersion (Figure 6C), as expected from the role of $\mathrm{C} 3 \mathrm{G}$ in adhesion and migration.

We next asked if Rap1 mediated C3G actions on foci formation. Single Rap1 knock-down led to a significant increase in the number of foci in p38 $\alpha$ knock-down HCT116 cells, but not in cells expressing p38 (Figure 6D). Rap1 depletion also increased the number of foci in C3G knock-down cells, not only in the absence of p38 $\alpha$, but also in its presence. This indicates that Rap1 does not mediate $\mathrm{C} 3 \mathrm{G}$ effects on anchorage-dependent growth.

Next, we analyzed the effect of $\mathrm{C} 3 \mathrm{G}$ on anchorageindependent growth. The number of foci was highly reduced upon C3G knock-down, p38 $\alpha$ knock-down,

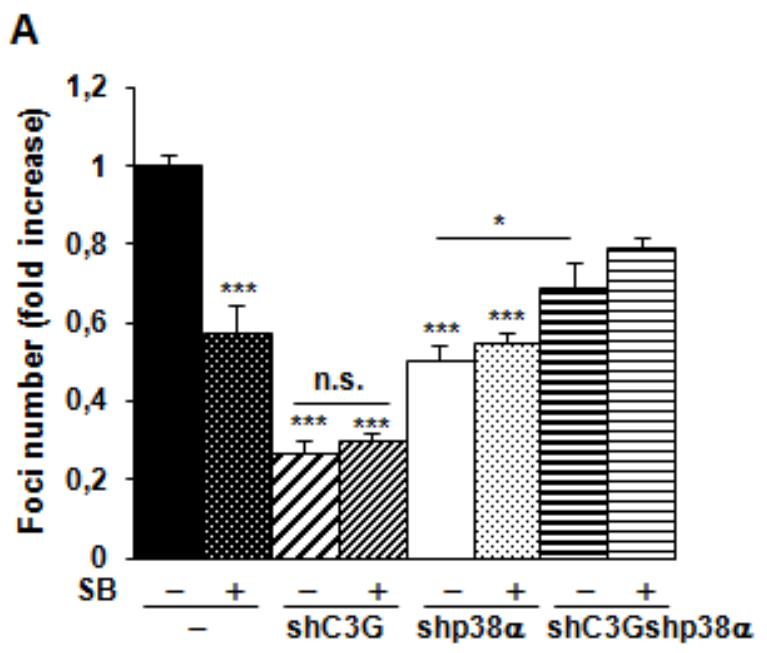

B
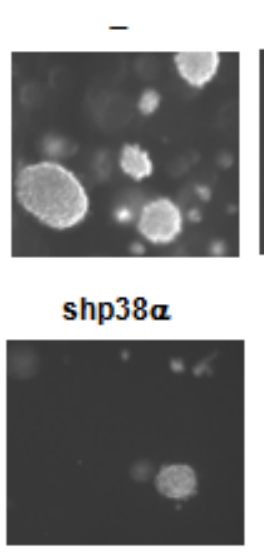

shC3G

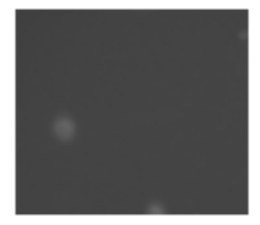

shC3Gshp38a

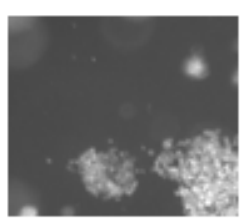

C

D
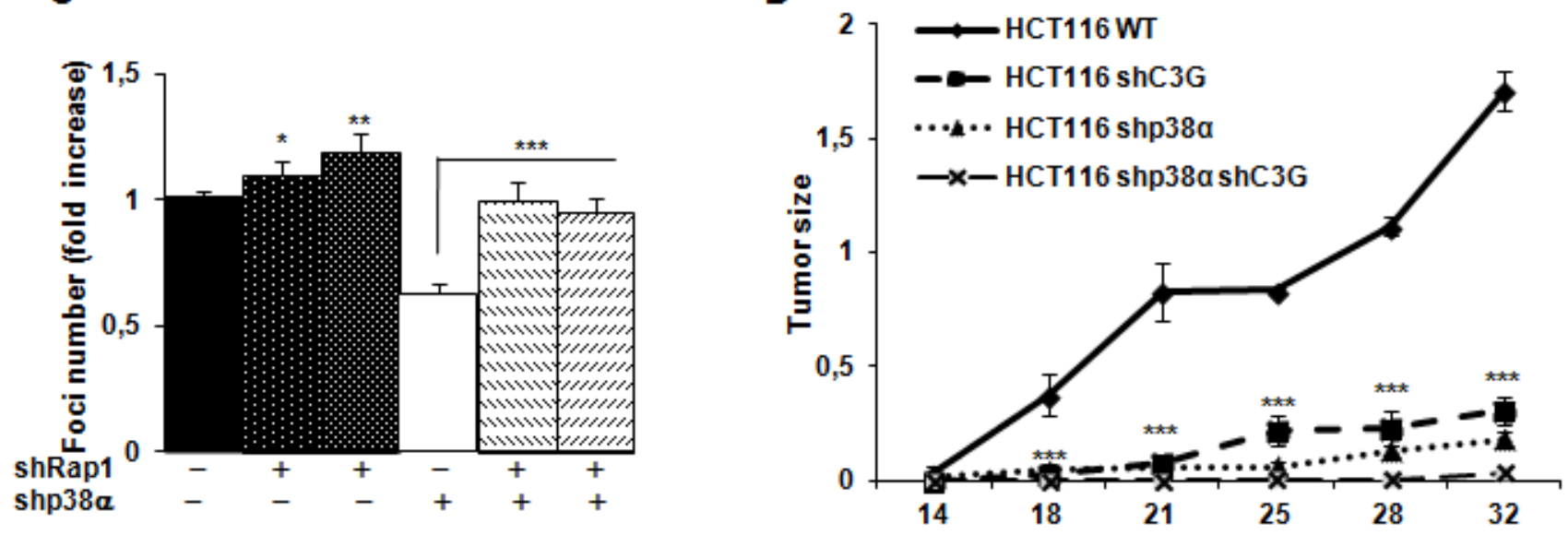

Figure 7: C3G and p38a MAPK promote tumor growth of HCT116 cells, while Rap1 does not. HCT116 cells (non-silenced

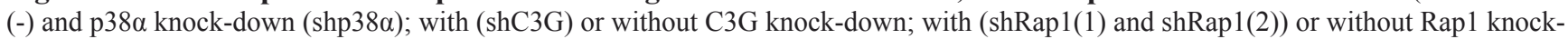
down) were used. A. and C. Anchorage independent growth of HCT116 cells at 14 days, in the absence or presence of SB203580 (10 $\mu \mathrm{M})$, as indicated. Histograms show the mean value \pm S.E.M. of the foci number expressed as the fold increase of non-silenced cells $(n=4)$. ${ }^{*} p<0.05,{ }^{*} p<0.01, * * * p<0.001$ as compared with non-silenced cells, or as indicated. B. Representative images of individual foci. D. Xenograft assay. Immunodeficient mice were injected subcutaneously with HCT116 cells. Tumor size was calculated by the formula ((L/2) $\mathrm{x}(\mathrm{W} / 2)) \mathrm{x} \pi$, where $\mathrm{L}$ and $\mathrm{W}$ are the longest and the shortest diameter in centimeters, respectively. Graphs show the mean value $\pm \mathrm{S}$.E.M. of tumor size at the indicated time points $(n=6) . *^{* *} p<0.001$ versus non-silenced cells. 
double C3G-p38 $\alpha$-knock-down or p38 $\alpha$ inhibition with SB203580 (Figure 7A). However, the largest reduction in the number of foci was observed in $\mathrm{C} 3 \mathrm{G}$ depleted HCT116 cells expressing p38 $\alpha$. Moreover, foci generated by non-silenced HCT116 cells are larger in size (Figure
7B). Curiously, C3G-p38 $\alpha$ double knock-down cells foci seemed to have less and more dispersed cells. On the other hand, foci number was increased upon Rap1 knock-down (Figure 7C), mainly in p38 $\alpha$ knock-down HCT116 cells, as observed in anchorage-dependent assays.

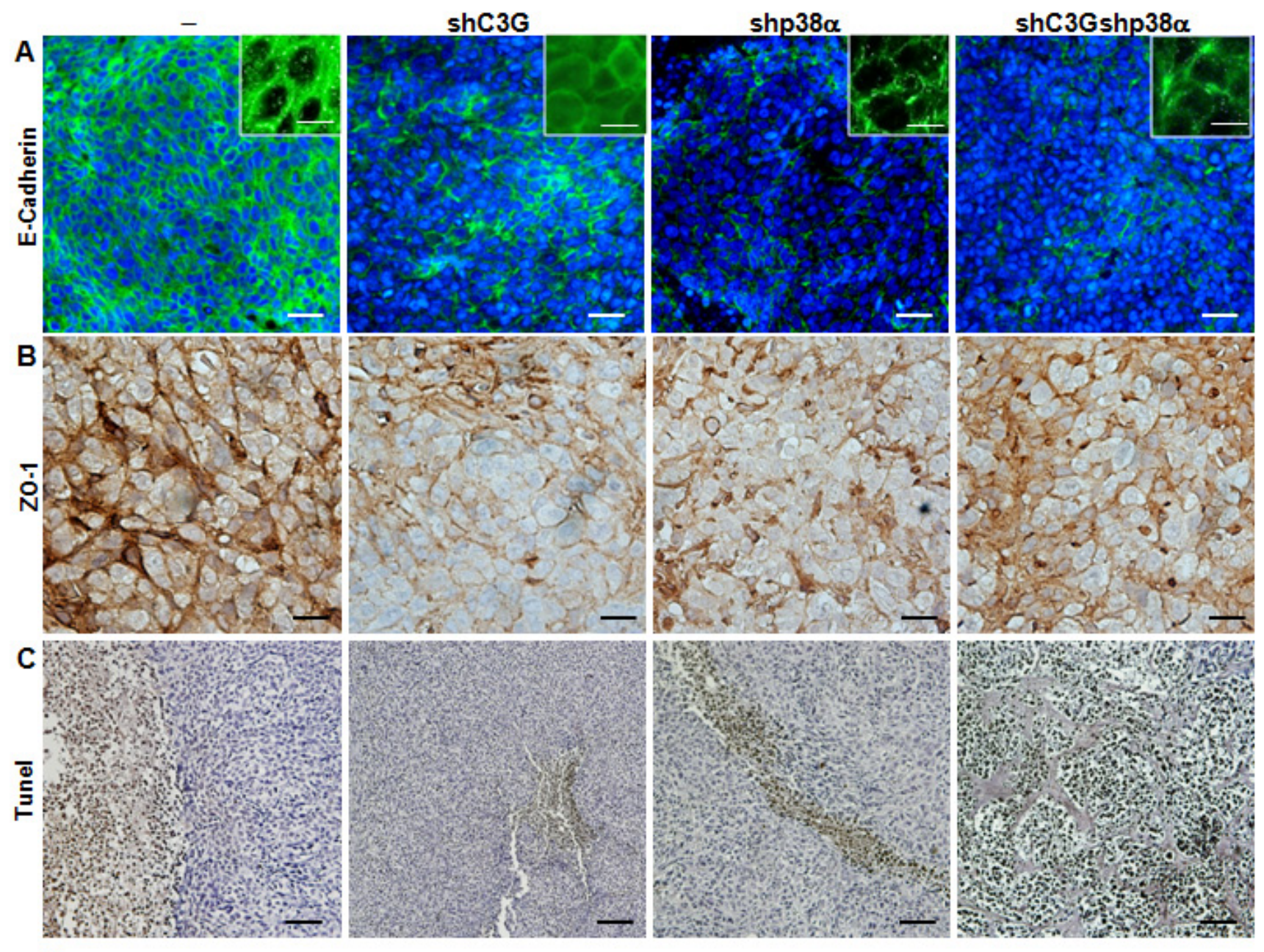

D

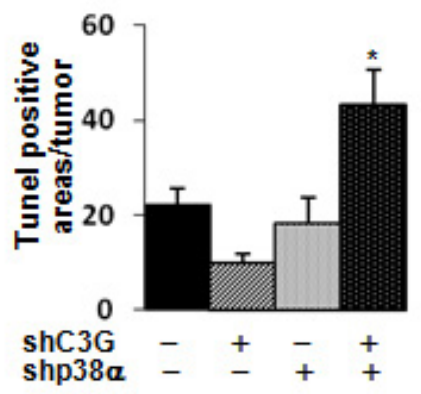

Figure 8: Analysis of E-cadherin, ZO-1 and cell death in tumors derived from C3G, p38 $\alpha$ and C3G-p38 $\alpha$ knock-down HCT116 cells. End point tumors generated from HCT116 cells (non-silenced (-) and p38a knock-down (shp38 $\alpha$ ); with (shC3G) or without $\mathrm{C} 3 \mathrm{G}$ knock-down) were analyzed. A. E-cadherin (green) and B. ZO-1 (brown) staining using specific antibodies. Inserts in A. show a higher amplification of images. C. Dead cells detected by Tunel assay (brown). D. Histogram showing the mean value \pm S.E.M. of the percentage of Tunel positive areas per tumor. ${ }^{*} p<0.05$ versus non-silenced cells. Scale bars: E-cadherin $30 \mu \mathrm{m}$ (inserts $10 \mu \mathrm{m}$ ); ZO-1 $20 \mu \mathrm{m}$; Tunel assay $50 \mu \mathrm{m}$. 
Finally, we assessed the involvement of $\mathrm{C} 3 \mathrm{G}$ on the tumorigenic activity of HCT116 cells in nude mice. Upon subcutaneous inoculation of control HCT116 cells, tumors were readily visible at 14 days and progressively grew over time (Figure 7D). Interestingly, tumor size was significantly reduced in cells subject to either $\mathrm{C} 3 \mathrm{G}$ or $\mathrm{p} 38 \alpha$ knock-down. Tumor growth was almost undetectable in cells with double C3G-p38 $\alpha$ knock-down.

To further understand the mechanisms involved in the in vivo regulation of tumor growth, we analyzed the morphology of tumor cells, as well as the presence of stromal cells and dead cells within the tumors. E-cadherin (Figure 8A) and ZO-1 (Figure 8B) expression decreased in xenografts derived from $\mathrm{C} 3 \mathrm{G}, \mathrm{p} 38 \alpha$ or C3G-p38 $\alpha$ double silenced HCT116 cells. Additionally, E-cadherin was partially internalized in $\mathrm{C} 3 \mathrm{G}$ knock-down cells (Figure 8A), which is consistent with the migration and invasion data. This disruption of cell-cell interactions might also contribute to the impaired tumor formation.
We also found a higher number of Tunel positive cells in C3G-p38 $\alpha$ double knock-down HCT116-derived tumors (Figure $8 \mathrm{C}$ and $8 \mathrm{D}$ ), with almost $70 \%$ of apoptotic cells in the small nodules. This suggests that depletion of $\mathrm{C} 3 \mathrm{G}$ and $\mathrm{p} 38 \alpha$ together sensitize cells to apoptotic stimuli, ultimately resulting in the inhibition of tumor formation. In agreement with this, oxidative stress $\left(\mathrm{H}_{2} \mathrm{O}_{2}\right)$ markedly reduced in vitro cell viability in these cells, with a magnitude larger than in single $\mathrm{C} 3 \mathrm{G}$ or $\mathrm{p} 38 \alpha$ knock-down HCT116 cells (Suppl. Figure 6). The lack of attachment also increased apoptosis in C3G-p38 $\alpha$ double knock-down cells in vitro, although single $\mathrm{C} 3 \mathrm{G}$ silencing had a greater effect (Suppl. Figure 7).

Finally, we observed elevated fibroblast infiltration in tumors with either $\mathrm{C} 3 \mathrm{G}$ and/or p38 $\alpha$ silencing (Figure 9A), whereas macrophage infiltration was decreased (Figure 9B). Furthermore, angiogenesis was clearly increased upon inhibition of $\mathrm{p} 38 \alpha$, as revealed by the increase in vessel density using by Meca 32 staining, and
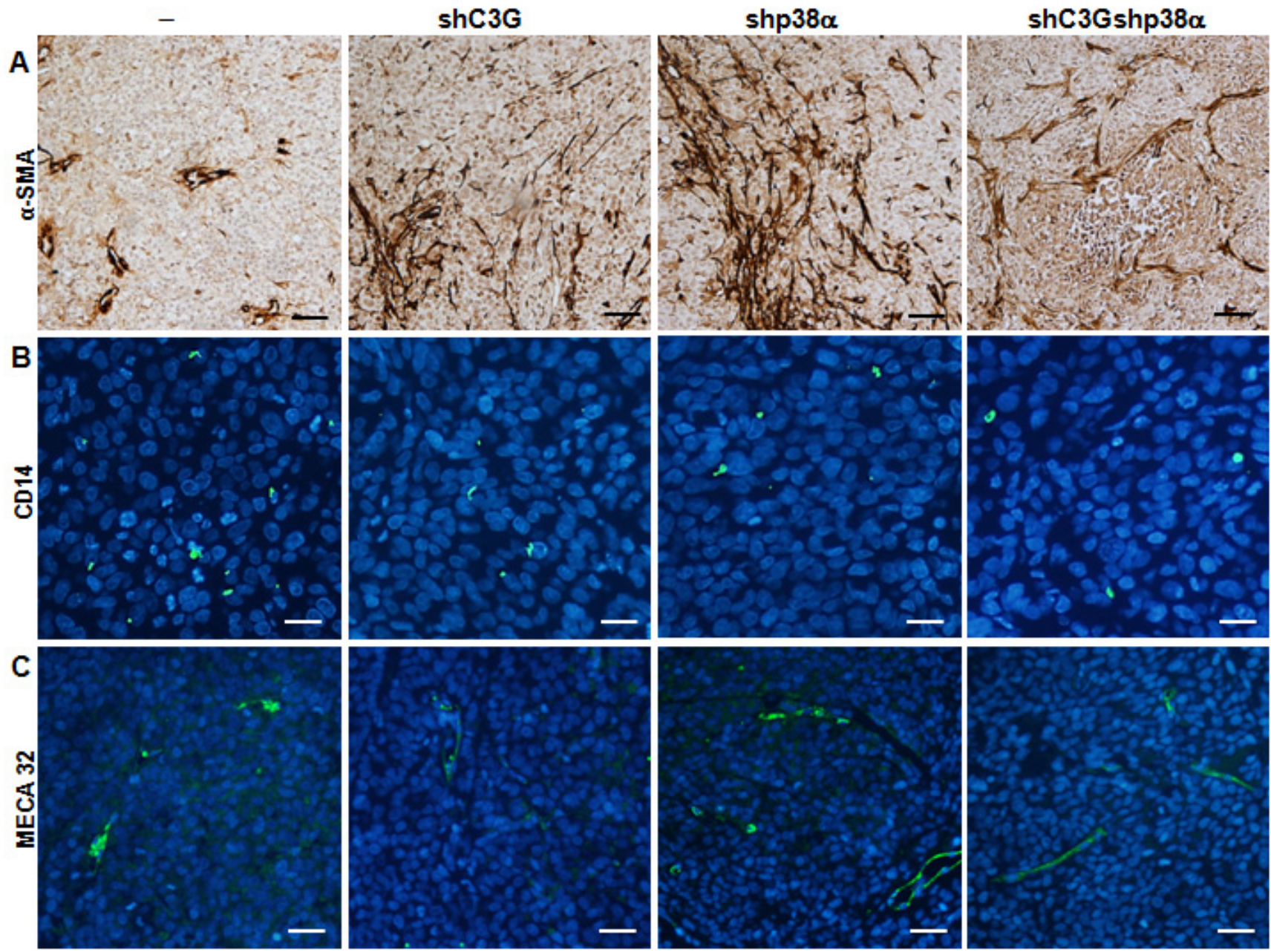

Figure 9: Analysis of infiltrated cells in tumors derived from C3G, p38 $\alpha$ and C3G-p38 $\alpha$ knock-down HCT116 cells. End point tumors generated from HCT116 cells (non-silenced (-) and p38 $\alpha$ knock-down (shp38 $\alpha$ ); with (shC3G) or without C3G knock-down) were analyzed. A. $\alpha$ SMA (brown), B. CD14 (green) and C. MECA32 (green) staining using specific antibodies. Scale bars: $\alpha$ SMA 50 $\mu$ M;

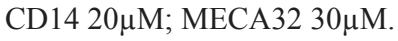


this effect was independent of C3G (Figure 9C).

\section{DISCUSSION}

The function of $\mathrm{C} 3 \mathrm{G}$ in cell migration has not been well characterized, although a number of studies indicate that it can play distinct specific roles depending on the context [3-6, 8]. For example, C3G deficient MEFs exhibited increased migration [3-4]. Accordingly, C3G overexpression reduced cell migration of highly invasive breast carcinoma cells [11]. In contrast, C3G/Rap1 pathway mediates IGF-1-induced migration of MCF7 breast cancer cells [43]. In this study, we demonstrate that in MEFs and HCT116 colon carcinoma cells, C3G down-regulates migration and invasion through a mechanism dependent on $\mathrm{p} 38 \alpha$. In fact, $\mathrm{C} 3 \mathrm{G}$ silencing enhances migration/invasion through the up-regulation of p38 $\alpha$ activity, which was impaired upon Rap1 silencing. Therefore, our results indicate that under physiological conditions, $\mathrm{C} 3 \mathrm{G}$ decreases migration and invasion through a mechanism that interferes with Rap1-dependent $\mathrm{p} 38 \alpha$ activation. This could involve specific protein-protein interactions rather than a GEF dependent mechanism [9$11,16,34]$, such as a direct $\mathrm{C} 3 \mathrm{G}$ and $\mathrm{p} 38 \alpha$ interaction, as observed in CML cells [34]. However, upon C3G downregulation, other Rap1 GEFs [13, 42] would enhance Rap1 activation as a compensatory mechanism, leading to $\mathrm{p} 38 \alpha$
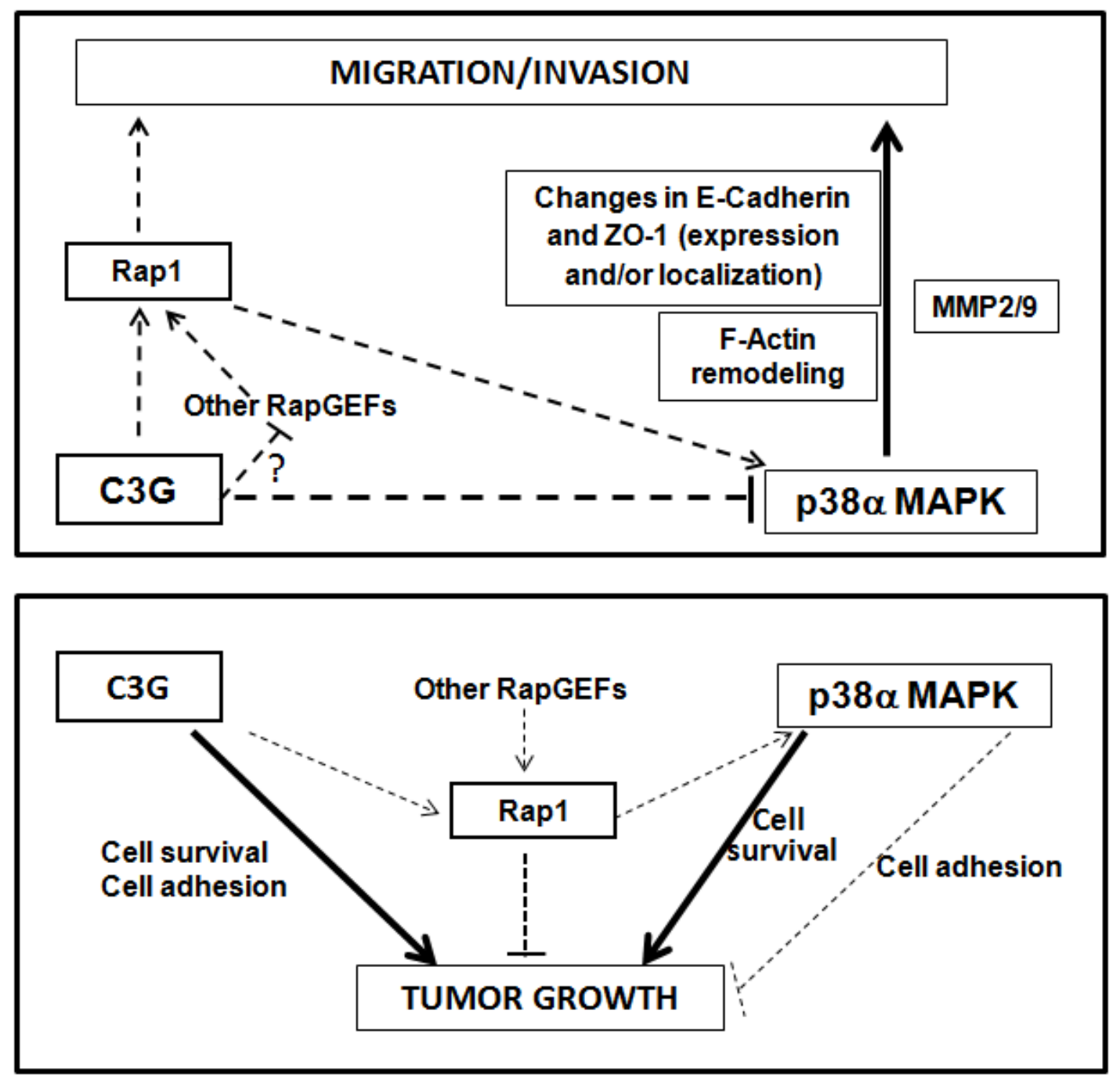

Figure 10: Scheme showing the interplay between C3G, p38 $\alpha$ and Rap1 to regulate cell migration, invasion and tumor growth of HCT116 cells. Upper panel, the diagram shows that C3G inhibits cell migration and invasion through down-regulation of p38 $\alpha$ activity, either by preventing Rap1-mediated p38 $\alpha$ activation by other Rap1GEFs or through p38 $\alpha$ inhibition by alternative mechanisms. $\mathrm{p} 38 \alpha$ promotes these processes. Changes in E-cadherin and ZO-1 expression and their cellular internalization, together with F-actin remodeling would mediate $\mathrm{C} 3 \mathrm{G} / \mathrm{p} 38 \alpha$ actions on migration and invasion. MMP2 and MMP9 contribute to $\mathrm{p} 38 \alpha$ induced invasion. Lower panel, the diagram shows that $\mathrm{C} 3 \mathrm{G}$ and $\mathrm{p} 38 \alpha$ promote tumor growth probably through independent pathways, inducing cell survival. Additionally, C3G through activation of cell adhesion may favor tumor growth. Rap1 inhibits tumor growth mainly through p38 $\alpha$ independent mechanisms, although Rap1-mediated p38 $\alpha$ activation could also prevent tumor growth by decreasing cell adhesion. 
hyper-activation. This is supported by the fact that Rap1GTP levels were up-regulated in C3G-silenced MEFs under growing conditions or in response to certain stimuli such as osmotic stress (Suppl. Figure 8).

Our findings support the concept that Rap1 promotes cell migration and invasion, as previously shown in several cancer cell lines [43-49]. Accordingly, optimal cell migration was associated with cycles of Rap1 activation [49]. Additionally, our data indicate that Rap1mediated $\mathrm{p} 38 \alpha$ activation is required to promote migration and invasion. This agrees with the function of Rap1 as an activator of p38 in response to FGF-2 in endothelial cells [50]. However, Rap1 can also inhibit p38 activation [51] or act in a parallel pathway in other contexts [52].

Our results also support a central role for $\mathrm{p} 38 \alpha$ in the actions of $\mathrm{C} 3 \mathrm{G}$ on migration and invasion. We and others have previously shown that $\mathrm{p} 38 \alpha$ plays roles in different aspects of cell migration, invasion and metastasis, favoring tumor progression $[27,37]$. p38 $\alpha$ mediates migration in HeLa cells and MEFs through the regulation of actin cytoskeleton via MK2 [28]. In HGF/Met-activated cortical neurons, the Rac $1 / \mathrm{p} 38$ cascade is also crucial for migration [53]. p38 $\alpha$ can also induce a cytoskeletal remodeling and a migratory response in tumor cells through Hsp27 phosphorylation [54]. Our results indicate that $\mathrm{C} 3 \mathrm{G}$, acting through $\mathrm{p} 38 \alpha$, regulates actin cytoskeleton organization in HCT116 cells. Thus, in C3G silenced cells, p38 $\alpha$ hyperactivation promotes the formation of filopodia and other migratory structures. In addition, C3G depletion induces internalization of ZO-1 and partial loss of E-cadherin, which disrupts cell-cell interactions and favors cell migration. This is also supported by in vivo data derived from xenografts assays, which show a reduction in ZO-1 and E-cadherin expression as well as a partial internalization of E-cadherin. In MEFs, C3G down-regulation also leads to a p38 $\alpha$-dependent actin reorganization (data not shown) and a loss of cell-cell contacts (Suppl. Video MEFs-shC3G).

In melanoma cells [22] or ovarian cancer cells [55], p38 MAPK promotes cell migration and invasion through regulation of MMP9. p38 $\alpha$ also induces the expression of MMP1, MMP2, MMP9 and MMP13 in other types of cancer [37]. Our results indicate that C3G silencingmediated $\mathrm{p} 38 \alpha$ hyperactivation increases MMP2 and MMP9 activities in MEFs and HCT116 colon carcinoma cells, which correlates with the effect on cell migration and invasion. This fits with our previous observations that p38 $\alpha$ is a positive regulator of MMP2 and MMP9 activities [27]. Rap1 also activates MMP2 and MMP9 in cells expressing p38 $\alpha$, in agreement with the role of Rap1 in inducing MMP9 secretion and invasion in head and neck squamous carcinoma cells [56]. Recent published data also suggest that $\mathrm{C} 3 \mathrm{G}$, acting through Rap1, promotes invasion of epithelial ovarian cancer cells through induction of MMP2 and MMP9 secretion [20].

Our studies using HCT116 colon carcinoma cells also revealed a positive role for both $\mathrm{p} 38 \alpha$ and $\mathrm{C} 3 \mathrm{G}$ in promoting in vitro and in vivo tumor growth. Our data support the concept that $\mathrm{C} 3 \mathrm{G}$ regulates tumor growth mainly through $\mathrm{p} 38 \alpha$ independent mechanisms, which differs from the mechanism by which it regulates migratory and invasive responses. Additionally, Rap1 does not mediate these $\mathrm{C} 3 \mathrm{G}$-driven effects either, but rather counteracts them. Results from our in vivo studies revealed that $\mathrm{C} 3 \mathrm{G}$ and $\mathrm{p} 38 \alpha$ double knock-down lead to a larger reduction in tumor size relative to each individual knockdown. However, this was not observed in anchoragedependent or -independent growth assays, where the number of foci was higher in the double knock-down than in C3G knock-down, although there were fewer cells per focus. One plausible explanation for the discrepancy between in vitro and in vivo results may be that in the in vivo context, other mechanisms may influence the $\mathrm{C} 3 \mathrm{G}$ response. In fact, enhanced cell death is observed in these C3G-p38 $\alpha$ knock-down-derived tumors, which may limit tumor development. This is also supported by the low viability detected in vitro in C3G-p38a silenced HCT116 cells subjected to oxidative stress (Suppl. Figure 6) or to a lack of attachment (Suppl. Figure 7). However, although the presence of dead cells in xenografts from single $\mathrm{C} 3 \mathrm{G}$ knock-down cells at the end point was quite low, apoptosis induced in vitro by the loss of attachment was enhanced in these cells. This fact, together with the low adhesion of these cells, might explain the impairment in tumor cell growth in vivo and in vitro. In fact, the low adhesion observed in $\mathrm{C} 3 \mathrm{G}$ knock-down cells correlates with a low number of foci. p38 $\alpha$ inhibition with SB203580 or Rap1 knock-down counteracted this effect of $\mathrm{C} 3 \mathrm{G}$ silencing on adhesion, increasing also the number of foci. Hence, Rap1mediated p38 $\alpha$ hyperactivation might limit cell attachment and tumor growth upon $\mathrm{C} 3 \mathrm{G}$ depletion, although other Rap1 independent mechanisms might contribute to the reduced tumor growth (Figure 10).

Overall, our data demonstrate that $\mathrm{C} 3 \mathrm{G}$ downregulation promotes migration and invasion in MEFs and HCT116 colon carcinoma cells through a mechanism that requires p38 $\alpha$ activation, and that may be mediated by Rap1 hyperactivation by other Rap1 GEFs (Figure 10). Down-regulation or inactivation of Rap1 impairs migration and invasion as a consequence of the low p38 $\alpha$ activity. On the other hand, $\mathrm{C} 3 \mathrm{G}$ and $\mathrm{p} 38 \alpha$ promote growth of HCT116 cells in vitro and in vivo, most likely through different mechanisms. The effect of $\mathrm{C} 3 \mathrm{G}$ might be dependent on its pro-adhesive and pro-survival activities (Figure 10), which might allow attachment and subsequent proliferation and/or survival of the cells. The pro-adhesive effect of C3G would be partially counteracted by Rap1mediated p38 $\alpha$ activation, although Rap1 would also inhibit tumor growth through other effectors. In addition, p38 a might promote cell survival and/or proliferation as previously demonstrated $[28,57]$ through C3G-Rap1 independent mechanisms. 


\section{MATERIALS AND METHODS}

\section{Cell lines and cell culture}

Wt and p38 $\alpha-/$-mouse embryonic fibroblasts (MEFs) were generated in our laboratory and immortalized by passages. C3G was permanently silenced using a $\mathrm{C} 3 \mathrm{G}$ shRNA inserted in the pSuper.retro.puro vector [33] and cells were selected with $2 \mu \mathrm{g} / \mathrm{ml}$ puromycin (SigmaAldrich P8833). To inhibit Rap1 function, MEFs (wt and p38 $\alpha$-deficient) expressing a Rap1 dominant-negative (with Ser17 mutated to Asn) were previously generated and selected with $2 \mu \mathrm{g} / \mathrm{ml}$ hygromycin [33].

The human colorectal carcinoma HCT116 cell line was obtained from ATCC (CCL-247) and authenticated by microsatellite markers analysis. HCT116 cells with permanent $\mathrm{p} 38 \alpha$ knock-down were previously generated using a p38a shRNA inserted in pSuper.retro.puro vector [58] and selected with $2 \mu \mathrm{g} / \mathrm{ml}$ puromycin. As a control, cells transfected with the empty vector were also generated. C3G was stably knocked-down by infection with human C3G shRNAs Lentiviral Particles (75000 infectious units) containing a mixture of different shRNAs (Santa Cruz Biotechnology sc-29863-V) in the presence of $10 \mu \mathrm{g} / \mathrm{ml}$ Polybrene (Santa Cruz Biotechnology sc134220) or a control shRNA for non-silenced cells. Cells were selected with puromycin $(2 \mu \mathrm{g} / \mathrm{ml})$ and several clones were obtained, keeping those with $\mathrm{C} 3 \mathrm{G}$ protein levels ranging between 30 and $40 \%$. Different clones were used for the main experiments.

Rap1 was knocked-down using two different specific shRNAs (shRap1(1) and shRap1(2)) against human Rap1 (Sigma TRCN0000029784 and TRCN0000029788, respectively) by transient transfections (using Metafectene-Pro) with a plasmid carrying shRNA 1 or 2.

MEFs were grown in DMEM medium and HCT116 cells in McCoy's (Invitrogen) medium supplemented with $10 \%$ fetal bovine serum (FBS) plus antibiotics at $37^{\circ} \mathrm{C}, 5 \%$ $\mathrm{CO}_{2}$ in a humidified atmosphere.

p38 $\alpha$ and/or p38 $\beta$ were inhibited with SB203580 (Calbiochem; 559389) at 5-10 $\mu \mathrm{M}$.

\section{Cell extracts preparation and western-blot analysis}

Cells were lysed in a buffer containing $50 \mathrm{mM}$ Tris $\cdot \mathrm{HCl}(\mathrm{pH} 7.5), 150 \mathrm{mM} \mathrm{NaCl}, 1 \% \mathrm{NP} 40,5 \mathrm{mM}$ EGTA, $5 \mathrm{mM}$ EDTA, $1 \mathrm{mM}$ phenylmethylsulfonyl fluoride, $10 \mu \mathrm{g} / \mathrm{ml}$ aprotinin, $10 \mu \mathrm{g} / \mathrm{ml}$ leupeptin, $1 \mathrm{mM}$ $\mathrm{Na}_{3} \mathrm{VO}_{4}$ and $20 \mathrm{mM} \mathrm{NaF}$ and centrifuged (at $13.000 \mathrm{rpm}$ $10 \mathrm{~min}, 4^{\circ} \mathrm{C}$ ). Supernatants (total cell extracts) were stored at $-80^{\circ} \mathrm{C}$. Protein concentration was determined by the Bradford method.

Western-blot analysis was carried out as previously described [30] using total cell extracts. Proteins were separated by electrophoresis using Anderson gels [59] (or SDS-page gels) and transferred to nitrocellulose membranes that were probed with the following antibodies against: P-p38MAPK (9211) P-ERKs (9101), P-Ser 473 Akt (9271) from Cell Signaling Technology, C3G (H-300) (sc-15359), Rap1 (sc-65), p38a MAPK (sc-535) from Santa Cruz Biotechnology, E-cadherin (BD 610182), ZO-1 (Invitrogen 617300) and $\beta$-actin (Sigma A5441).

\section{Wound healing assays}

Confluent cells were pre-treated with mitomycin C (25 $\mu \mathrm{g} / \mathrm{ml}$, Sigma-Aldrich M0503) for $30 \mathrm{~min}$ to inhibit cell growth. Then, a straight scratch was performed and the medium replaced by a fresh one without serum (for MEFs) or with 2\% FBS (for HCT116 cells). Cells were maintained for $8 \mathrm{~h}-48 \mathrm{~h}$ at $37^{\circ} \mathrm{C}$ and $5 \% \mathrm{CO}_{2}$. Migration was followed by a phase-contrast microscope (Eclipse TE300 Nikon coupled to a digital camera) at different time points. Photographs were taken to quantify (using TScratch program) the percentage of wound healing closure at the different times.

\section{Invasion assays}

Invasion was assayed using Matrigel $(444 \mu \mathrm{g} /$ $\mathrm{cm}^{2}$ ) (BD Biosciences, 356234) coated transwells (8 $\mu \mathrm{m}$ filter, BD 353097). Cells (20.000-50.000) were seeded in the upper chamber in a serum-free medium. In the lower chamber, FBS (10\%) or HGF (40 ng/ml) was added to the medium to act as a chemoattractant. Then, cells were incubated for $24 \mathrm{~h}$ at $37^{\circ} \mathrm{C}, 5 \% \mathrm{CO}_{2}$ in a humidified atmosphere. Medium and Matrigel from the upper chamber were removed and cells present in the lower chamber were fixed with $4 \%$ paraformaldehyde and stained with crystal violet $0.2 \% \mathrm{p} / \mathrm{v}$ (Sigma-Aldrich C-0775). Cells were counted using a phase-contrast microscope.

\section{Quantification of MMP2/9 by zymography}

To determine MMP2 and MMP9 activities, 80\% confluent cells were serum-deprived for $24-48 \mathrm{~h}$ and the culture medium was used for an electrophoresis in $8 \%$ SDS-polyacrylamide gels polymerized in the presence of $0.1 \%$ gelatin under non-reducing conditions. Gels were washed with $2.5 \%$ Triton X-100 (30 min) to remove SDS, rinsed with substrate buffer $\left(0.2 \mathrm{M} \mathrm{NaCl}, 5 \mathrm{mM} \mathrm{CaCl}_{2}\right.$, $1 \%$ Triton $\mathrm{X} 100,0.02 \% \mathrm{NaN}_{3}, 50 \mathrm{mM}$ Tris $\mathrm{pH} 7.5$ ) and incubated in this buffer at $37^{\circ} \mathrm{C}$ overnight to allow protein renaturation and MMP activation. To visualize gelatin degradation, the gel was stained with Coomassie Brilliant Blue (BioRad, 161-0400). 


\section{Adhesion assays}

Trypsinized HCT116 cells were resuspended in McCoy's medium containing 10\% FBS, seeded and kept in the incubator at $37^{\circ} \mathrm{C}$ for $1 \mathrm{~h}$. After washing with PBS, adhered cells were stained with Crystal violet and counted under the microscope.

\section{Confocal microscopy analysis}

The subcellular localization of E-cadherin and $\mathrm{ZO}-1$ proteins was analyzed by confocal fluorescence microscopy using the same antibodies used for western blots. Cells were seeded on $2 \%$ gelatin-coated glass coverslips and fixed with $4 \%$ paraformaldehyde at room temperature (RT) for $30 \mathrm{~min}$. F-actin staining was performed using rhodamine-conjugated phalloidin as previously described [60]. To detect ZO-1, in addition to fixation, cells were permeabilized with $0.1 \%$ triton X-100 in $0.1 \%$ BSA-PBS for $20 \mathrm{~min}$ [60]. Fixed cells were incubated in blocking solution ( 2 \%BSA in PBS, 1 $h$ at RT), followed by an incubation with mouse anti-Ecadherin or rabbit anti-ZO-1 (dilution 1:50) in 0.1\% BSA PBS for $1 \mathrm{~h}$ at RT. After washing with PBS, cells were incubated for $1 \mathrm{~h}$ at RT with FITC-labelled anti-mouse or anti-rabbit Alexa 594 (dilution 1:200) in 0.1\% BSA PBS, respectively. After washing with PBS, cells were prepared for visualization by embedding in Vectashield mounting medium with DAPI and visualized in a Leica TCS-SL confocal microscope with a $63 \mathrm{X}$ objective.

\section{Focus formation assays}

To measure anchorage dependent growth, 300 cells (HCT116 cells) were seeded in a $10 \mathrm{~cm}$ dish. After 8-10 days, foci were stained with a $0.2 \%$ crystal violet solution. The total number of foci was quantified using Image $\mathrm{J}$ program and their size using OpenCFU program. The size of colonies was measured as volume applying the equation $4 / 3 \pi \mathrm{r} 3$, where $r$ is the radius of foci.

\section{Anchorage-independent growth in soft agar}

To measure anchorage-independent growth, cells were cultured in 24-well dishes containing two agar layers. Cells $\left(3 \times 10^{3}\right)$ were resuspended in $0.35 \%$ agar $(\mathrm{BD}$, 214530) (diluted in complete medium) and poured onto a $0.5 \%$ layer of agar (diluted in medium). Fresh medium was added to the top layer every 3 days. After 2 weeks, colonies were stained with $0.005 \%$ crystal violet and counted using a dissecting microscope.

\section{Xenograft assays}

HCT116 cells $\left(10^{6}\right.$ cells $\left./ 100 \mu \mathrm{l}\right)$ were resuspended in McCoy's medium and injected subcutaneously (s.c.) into the flank of eight-week old male nude mice (Harlam Laboratories). Tumor growth was monitored twice a week for 6 weeks. Tumor size was calculated by the formula $((\mathrm{L} / 2) \mathrm{x}(\mathrm{W} / 2)) \mathrm{x} \pi$, where $\mathrm{L}$ and $\mathrm{W}$ are the longest and the shortest diameter in centimeters, respectively. All animal experiments were carried out in compliance with the institutions guidelines.

\section{Immunohistochemical and immunofluorescence analysis of tumor samples}

Paraffin embedded sections from HCT116 tumors were used to detect E-cadherin (cell signaling, 3195S), ZO-1 (Life technologies, 339100), MECA 32 (BD Pharmigen, 550563), CD14 (BD Pharmigen, 553739), aSMA (DAKO, M0851) and cell death by Tunel (Roche, 11093070910). For immunohistochemical analysis of ZO-1 and $\alpha$ SMA and detection of cell death by Tunel, endogenous peroxidase activity was first quenched. Then, binding of the primary antibody (ZO-1 and $\alpha \mathrm{SMA}$ ) was carried out overnight at $4^{\circ} \mathrm{C}$, followed by secondary antibody incubation ( $1 \mathrm{~h}$ at RT), or alternatively, for Tunel assay, incubation for $1 \mathrm{~h}$ at $37^{\circ} \mathrm{C}$ with biotin 16 dUTP (Roche, 11093070910) in the reaction mixture was performed. Finally, samples were incubated with the avidin/biotin reagent (Vectastain $\mathrm{ABC}$ Kit) for 30 min at RT in the dark and the $\mathrm{dAB}$ reagent (Peroxidase Substrate Kit SK-4100). For immunofluorescence analysis of E-cadherin, MECA32 and CD14, incubation with the primary antibody (overnight at $4^{\circ} \mathrm{C}$ ) was followed by incubation ( $1 \mathrm{~h}$ at $\mathrm{RT})$ with the secondary antibodies: Alexa fluor 488 Goat anti-rabbit (Life technologies, A11034) for E-cadherin and Alexa Fluor 488 Goat antirat (Life technologies, A11006) for CD14 and MECA 32.

\section{Statistical analysis}

Data are represented as the mean values \pm SEM. An unpaired Student's $t$-test and Anova analysis were used.

\section{Abbreviations}

MAPKs, mitogen activated protein kinase, $\mathrm{C} 3 \mathrm{G}$, Crk SH3-domain-binding guanine nucleotide-releasing factor, MMPs, matrix metalloproteases.

\section{ACKNOWLEDGMENTS}

We thank Dr. Cesar Roncero for its help in video editing, and Isabel Peña and Raul Alonso Sabadell for her 
collaboration in the performance of some experiments.

\section{CONFLICTS OF INTEREST}

The authors declare no conflict of interest to declare.

\section{GRANT SUPPORT}

This work was supported by grants from the Spanish Ministry of Economy and Competitiveness (SAF201020918-C02-01 and SAF2013-48210-C2-02 to AP, SAF2010-20918-C02-02 and SAF2013-48210-C2-01 to CG), from Complutense University (AE1/14-18987 and UCM 920384 to AP), from the Council of Education from Junta de Castilla y León (SA157A12-1 to CG), and from the Cellex Foundation (PB). All funding was co-sponsored by the European FEDER Program. MA and NP are PhD student supported by the Spanish Ministry of Education (FPU fellowship). CS is a $\mathrm{PhD}$ student supported by SAF2013-48210-C2-02 grant. VM-G is supported by Dr. Moraza Foundation PhD fellowship. PB is supported by a Beatrius de Pinos postdoctoral Fellowship from the Generalitat de Catalunya (2014 BP-B 00160).

\section{REFERENCES}

1. Gotoh T, Hattori S, Nakamura S, Kitayama H, Noda M, Takai Y, Kaibuchi K, Matsui H, Hatase O and Takahashi H. Identification of Rap1 as a target for the Crk SH3 domainbinding guanine nucleotide-releasing factor C3G. Mol Cell Biol 1995; 15: 6746-6753.

2. Gotoh T, Niino Y, Tokuda M, Hatase O, Nakamura S, Matsuda M and Hattori S. Activation of R-Ras by Rasguanine nucleotide-releasing factor. J Biol Chem 1997; 272: 18602-18607.

3. Ohba Y, Ikuta K, Ogura A, Matsuda J, Mochizuki N, Nagashima K, Kurokawa K, Mayer BJ, Maki K, Miyazaki $\mathrm{J}$ and Matsuda M. Requirement for C3G-dependent Rap1 activation for cell adhesion and embryogenesis. EMBO J 2001; 20: 3333-3341.

4. Voss AK, Gruss P and Thomas T. The guanine nucleotide exchange factor $\mathrm{C} 3 \mathrm{G}$ is necessary for the formation of focal adhesions and vascular maturation. Development 2003; 130: 355-367.

5. Voss AK, Britto JM, Dixon MP, Sheikh BN, Collin C, Tan SS and Thomas T. C3G regulates cortical neuron migration, preplate splitting and radial glial cell attachment. Development 2008; 135: 2139-2149.

6. Yip YP, Thomas T, Voss AK and Yip JW. Migration of sympathetic preganglionic neurons in the spinal cord of a C3G-deficient mouse suggests that $\mathrm{C} 3 \mathrm{G}$ acts in the reelin signaling pathway. J Comp Neurol 2012; 520: 3194-3202.

7. Rufanova VA, Lianos E, Alexanian A, Sorokina E, Sharma M, McGinty A and Sorokin A. C3G overexpression in glomerular epithelial cells during anti-GBM-induced glomerulonephritis. Kidney Int 2009; 75: 31-40.

8. Dayma K and Radha V. Cytoskeletal remodeling by C3G to induce neurite-like extensions and inhibit motility in highly invasive breast carcinoma cells. Biochim Biophys Acta 2011; 1813: 456-465.

9. Guerrero C, Fernandez-Medarde A, Rojas JM, Font de Mora J, Esteban LM and Santos E. Transformation suppressor activity of $\mathrm{C} 3 \mathrm{G}$ is independent of its CDC25homology domain. Oncogene 1998; 16: 613-624.

10. Guerrero C, Martin-Encabo S, Fernandez-Medarde A and Santos E. C3G-mediated suppression of oncogeneinduced focus formation in fibroblasts involves inhibition of ERK activation, cyclin A expression and alterations of anchorage-independent growth. Oncogene 2004; 23 : 4885 4893.

11. Shivakrupa R, Radha V, Sudhakar C and Swarup G. Physical and functional interaction between Hck tyrosine kinase and guanine nucleotide exchange factor $\mathrm{C} 3 \mathrm{G}$ results in apoptosis, which is independent of $\mathrm{C} 3 \mathrm{G}$ catalytic domain. J Biol Chem 2003; 278: 52188-52194.

12. Huang $X, W u$ D, Jin H, Stupack D and Wang JY. Induction of cell retraction by the combined actions of Abl-CrkII and Rho-ROCK1 signaling. J Cell Biol 2008; 183: 711-723.

13. Pannekoek WJ, Kooistra MR, Zwartkruis FJ and Bos JL. Cell-cell junction formation: the role of Rap1 and Rap1 guanine nucleotide exchange factors. Biochim Biophys Acta 2009; 1788: 790-796.

14. Radha V, Rajanna A, Mitra A, Rangaraj N and Swarup G. C3G is required for c-Abl-induced filopodia and its overexpression promotes filopodia formation. Exp Cell Res 2007; 313: 2476-2492.

15. Kooistra MR, Dubé N and Bos JL. Rap1: a key regulator in cell-cell junction formation. J Cell Sci 2007; 120: 17-22.

16. Martín-Encabo S, Santos E and Guerrero C. C3G mediated suppression of malignant transformation involves activation of PP2A phosphatases at the subcortical actin cytoskeleton. Exp Cell Res 2007; 313: 3881-3891.

17. Okino K, Nagai H, Nakayama H, Doi D, Yoneyama K, Konishi $\mathrm{H}$ and Takeshita T. () Inactivation of Crk SH3 domain-binding guanine nucleotide-releasing factor $(\mathrm{C} 3 \mathrm{G})$ in cervical squamous cell carcinoma. Int J Gynecol Cancer 2006; 16: 763-771.

18. Hirata T, Nagai H, Koizumi K, OkinoK, Harada A, Onda M, Nagahata T, Mikami I, Hirai K, Haraguchi S, Jin E, Kawanami O, Shimizu K and Emi M. Amplification, upregulation and over-expression of $\mathrm{C} 3 \mathrm{G}$ (CRK SH3 domainbinding guanine nucleotide-releasing factor) in non-small cell lung cancers. J Hum Genet 2004; 49: 290-295.

19. Gutierrez-Berzal J, Castellano E, Martin-Encabo S, Gutierrez-Cianca N, Hernandez JM, Santos E and Guerrero C. Characterization of $\mathrm{p} 87 \mathrm{C} 3 \mathrm{G}$, a novel, truncated $\mathrm{C} 3 \mathrm{G}$ isoform that is overexpressed in chronic myeloid leukemia 
and interacts with Bcr-Abl. Exp Cell Res 2006; 312: 938948.

20. Che YL, Luo SJ, Li G, Cheng M, Gao YM, Li XM, Dai JM, He H, Wang J, Peng HJ, Zhang Y, Li WY, Wang H, Liu B and Linghu $\mathrm{H}$. The $\mathrm{C} 3 \mathrm{G} / \mathrm{Rap} 1$ pathway promotes secretion of MMP-2 and MMP-9 and is involved in serous ovarian cancer metastasis. Cancer Lett 2015; 359: 241-249.

21. Samuelsson J, Alonso S, Ruiz-Larroya T, Cheung TH, Wong YF and Perucho M. Frequent somatic demethylation of RAPGEF1/C3G intronic sequences in gastrointestinal and gynecological cancer. Int J Oncol 2011; 38: 1575-1577.

22. Wagner EF and Nebreda AR. Signal integration by JNK and p38 MAPK pathways in cancer development. Nat Rev Cancer 2009; 9: 537-549.

23. Lafarga V, Cuadrado A, López de Silanes I, Bengoechea R, Fernandez-Capetillo O and Nebreda AR. p38 Mitogenactivated protein kinase- and HuR-dependent stabilization of p21(Cip1) mRNA mediates the G(1)/S checkpoint. Mol Cell Biol 2009; 29: 4341-4351.

24. Dolado I, Swat A, Ajenjo N, De Vita G, Cuadrado A and Nebreda AR. p38alpha MAP kinase as a sensor of reactive oxygen species in tumorigenesis. Cancer Cell 2007; 11: 191-205.

25. Leelahavanichkul K, Amornphimoltham P, Molinolo AA, Basile JR, Koontongkaew S and Gutkind JS. A role for p38 MAPK in head and neck cancer cell growth and tumorinduced angiogenesis and lymphangiogenesis. Mol Oncol 2014; 8: 105-118.

26. Ranganathan AC, Adam AP, Zhang L and Aguirre-Ghiso JA. Tumor cell dormancy induced by p38SAPK and ERstress signaling: an adaptive advantage for metastatic cells? Cancer Biol Ther 2006; 5: 729-735.

27. Arechederra M, Priego N, Vázquez-Carballo A, Sequera C, Gutiérrez-Uzquiza Á, Cerezo-Guisado MI, OrtizRivero S, Roncero C, Cuenda A, Guerrero C and Porras A. p38 MAPK down-regulates fibulin 3 expression through methylation of gene regulatory sequences: role in migration and invasion. J Biol Chem 2015; 290: 4383-4397.

28. Rousseau S, Dolado I, Beardmore V, Shpiro N, Marquez R, Nebreda AR, Arthur JS, Case LM, Tessier-Lavigne M, Gaestel M, Cuenda A and Cohen P. CXCL12 and C5a trigger cell migration via a PAK1/2-p38alpha MAPKMAPKAP-K2-HSP27 pathway. Cell Signal 2006; 18: $1897-$ 1905.

29. Guo YL and Yang B. Altered cell adhesion and cell viability in a p38alpha mitogen-activated protein kinase-deficient mouse embryonic stem cell line. Stem Cells Dev 2006; 15: 655-664.

30. Zuluaga S, Gutierrez-Uzquiza A, Bragado P, AlvarezBarrientos A, Benito M, Nebreda AR and Porras A. p38a MAPK can positively or negatively regulate Rac-1 activity depending on the presence of serum. FEBS Lett 2007; 581: 3819-3825.

31. Gupta J, Del Barco Barrantes I, Igea A, Sakellariou S,
Pateras IS, Gorgoulis VG and Nebreda AR. Dual function of $\mathrm{p} 38 \alpha$ in colon cancer: Suppression of colitis-associated tumor initiation, but requirement for cancer cell survival. Cancer Cell 2014; 25: 484-500.

32. Maia V, Sanz M, Gutierrez-Berzal J, de Luis A, GutierrezUzquiza A, Porras A, Guerrero C. C3G silencing enhances STI-571-induced apoptosis in CML cells through p38 MAPK activation, but it antagonizes STI-571 inhibitory effect on survival. Cell Signal 2009; 21: 1229-1235.

33. Gutiérrez-Uzquiza A, Arechederra M, Molina I, Baños R, Maia V, Benito M, Guerrero C and Porras A. C3G downregulates $\mathrm{p} 38$ MAPK activity in response to stress by Rap-1 independent mechanisms: involvement in cell death. Cell Signal 2010; 22: 533-542.

34. Maia V, Ortiz-Rivero S, Sanz M, Gutiérrez-Berzal J, Alvarez-Fernández I, Gutiérrez-Herrero S, de Pereda JM, Porras A and Guerrero C. C3G forms complexes with Bcr$\mathrm{Abl}$ and $\mathrm{p} 38 \alpha \mathrm{MAPK}$ at the focal adhesions in chronic myeloid leukemia cells: implication in the regulation of leukemic cell adhesion. Cell Commun Signal 2013; 11: 9.

35. Kessenbrock K, Plaks V and Werb Z. Matrix metalloproteinases: regulators of the tumor microenvironment. Cell 2010; 141: 52-67.

36. Mason SD and Joyce JA. Proteolytic networks in cancer. Trends Cell Biol 2011; 21: 228-237.

37. del Barco Barrantes I and Nebreda AR. Roles of p38 MAPKs in invasion and metastasis. Biochem Soc Trans 2012; 40: 79-84.

38. Parsons JT, Horwitz AR and Schwartz MA. Cell adhesion: integrating cytoskeletal dynamics and cellular tension. Nat Rev Mol Cell Biol 2010; 11: 633-643.

39. Thiery JP, Acloque H, Huang RY and Nieto MA. Epithelialmesenchymal transitions in development and disease. Cell 2009; 139: 871-890.

40. Lamouille S, Xu J and Derynck R. Molecular mechanisms of epithelial-mesenchymal transition. Nat Rev Mol Cell Biol 2014; 15:178-196.

41. Hogan C, Serpente N, Cogram P, Hosking CR, Bialucha CU, Feller SM, Braga VM, Birchmeier W and Fujita Y. Rap1 regulates the formation of E-cadherin-based cell-cell contacts. Mol Cell Biol 2004; 24: 6690-6700.

42. Kooistra MR, Dubé N and Bos JL. Rap1: a key regulator in cell-cell junction formation. J Cell Sci 2007; 120: 17-22.

43. Guvakova MA, Lee WS, Furstenau DK, Prabakaran I, Li DC, Hung R and Kushnir N. The small GTPase Rap1 promotes cell movement rather than stabilizes adhesion in epithelial cells responding to insulin-like growth factor I. Biochem J 2014; 463: 257-270.

44. Hattori $M$ and Minato N. Rap1 GTPase: functions, regulation, and malignancy. J Biochem 2003; 134: 479-484.

45. Lin KB, Freeman SA and Gold MR. Rap GTPasemediated adhesion and migration: A target for limiting the dissemination of B-cell lymphomas? Cell Adh Migr 2010; 4: 327-332. 
46. Kim WJ, Gersey Z and Daaka Y. Rap1GAP regulates renal cell carcinoma invasion. Cancer Lett 2012; 320: 65-71.

47. Bailey CL, Kelly P and Casey PJ. Activation of Rap1 promotes prostate cancer metastasis. Cancer Res 2009; 69: 4962-4968.

48. McSherry EA, Brennan K, Hudson L, Hill AD and Hopkins A M. Breast cancer cell migration is regulated through junctional adhesion molecule-A-mediated activation of Rap1 GTPase. Breast Cancer Res 2011; 13: R31.

49. Takahashi M, Dillon TJ, Liu C, Kariya Y, Wang Z and Stork P J. Protein kinase A-dependent phosphorylation of Rap1 regulates its membrane localization and cell migration. J Biol Chem 2013; 288: 27712-27723.

50. Yan J, Li F, Ingram DA and Quilliam LA. Rap1a is a key regulator of fibroblast growth factor 2-induced angiogenesis and together with Rap1b controls human endothelial cell functions. Mol Cell Biol 2008; 28: 5803-5810.

51. Palsson EM, Popoff M, Thelestam M and O'Neill LA. Divergent roles for Ras and Rap in the activation of p38 mitogen-activated protein kinase by interleukin-1. J Biol Chem 2000; 275: 7818-7825.

52. Yi L, Chandrasekaran P and Venkatesan S. TLR signaling paralyzes monocyte chemotaxis through synergized effects of p38 MAPK and global Rap-1 activation. PLoS One 2012; 7: e30404.

53. Segarra J, Balenci L, Drenth T, Maina F and Lamballe F. Combined signaling through ERK, PI3K/AKT, and RAC1/ p38 is required for met-triggered cortical neuron migration. J Biol Chem 2006; 281: 4771-4778.

54. Laferriere J, Houle F, Taher MM, Valerie K and Huot J. Transendothelial migration of colon carcinoma cells requires expression of E-selectin by endothelial cells and activation of stress-activated protein kinase-2 (SAPK2/p38) in the tumor cells. J Biol Chem 2001; 276: 33762-33772.
55. Zhou HY, Pon YL and Wong AS. Synergistic effects of epidermal growth factor and hepatocyte growth factor on human ovarian cancer cell invasion and migration: role of extracellular signal-regulated kinase $1 / 2$ and p38 mitogenactivated protein kinase. Endocrinology 2007; 148: 51955208.

56. Mitra RS, Goto M, Lee JS, Maldonado D, Taylor JM, Pan Q, Carey TE, Bradford CR, Prince ME, Cordell KG, Kirkwood KL and D'Silva NJ. Rap1GAP promotes invasion via induction of matrix metalloproteinase 9 secretion, which is associated with poor survival in low N-stage squamous cell carcinoma. Cancer Res 2008; 68: 3959-3969.

57. Gupta J, Igea A, Papaioannou M, Lopez-Casas PP, Llonch E, Hidalgo M, Gorgoulis VG, Nebreda AR. Pharmacological inhibition of p38 MAPK reduces tumor growth in patient-derived xenografts from colon tumors. Oncotarget 2015; 6: 8539-8551. doi: 10.18632/ oncotarget.3816.

58. Bragado P, Armesilla A, Silva A and Porras A. Apoptosis by cisplatin requires p53 mediated p38alpha MAPK activation through ROS generation. Apoptosis 2007; 12: 1733-1742.

59. Nebreda AR, Gannon JV and Hunt T. Newly synthesized protein(s) must associate with $\mathrm{p} 34 \mathrm{cdc} 2$ to activate MAP kinase and MPF during progesterone-induced maturation of Xenopus oocytes. EMBO J 1995; 14: 5597-5607.

60. Suárez-Causado A, Caballero-Díaz D, Bertrán E, Roncero C, Addante A, García-Álvaro M, Fernández M, Herrera B, Porras A, Fabregat I and Sánchez A. HGF/c-Met signaling promotes liver progenitor cell migration and invasion by an epithelial-mesenchymal transition-independent, phosphatidyl inositol-3 kinase-dependent pathway in an in vitro model. Biochim Biophys Acta 2015; 1853: 2453 2463. 